Status Report 2016-2019

\title{
Marine Micropalaeontology: An Overview of Indian Contributions During 2016-2019
}

\author{
M C MANOJ, ABHA SINGH, POONAM VERMA, PAWAN GOVIL, MASUD KAWSAR, PREM RAJ \\ UDDANDAM and VANDANA PRASAD* \\ Birbal Sahni Institute of Palaeosciences, 53, University Road, Lucknow 226 007, India
}

(Received on 19 September 2019; Accepted on 29 September 2019)

\begin{abstract}
Marine micropaleontology concerns biostratigraphy for dating and correlation of deep time sequences as well as in palaeoceanography to understand the marine processes of the past. For this, marine micropalaeontology utilizes detailed studies on exclusively marine microbiota such as foraminifers, nannofossils, diatoms, dinoflagellates, and others. This article discusses (in detail) our present state of palaeoceanographic knowledge based on marine micropalaeontology studies in the Indian sector. A detailed literature survey showcases that numerous studies have been carried out in deep time (Jurassic - Neogene) as well as Quaternary sediments utilizing marine microfossils from India. These studies from different geological periods and regions within the Indian territory such as Jurassic (Kutch Basin), Cretaceous and CretaceousPaleogene (K-Pg) transition (western, peninsular and northeast India), Palaeogene (northeast and western India), Neogene (Andaman \& Nicobar Islands, northeast Indian Ocean), Quaternary (Indian Ocean, Southern Ocean, coastal and estuarine regions of peninsular India) have provided better insights to our previous understandings on various aspects that include biostratigraphy, paleoenvironment, evolution, ocean/land-climate variability, its dynamics and teleconnections.
\end{abstract}

Keywords: Micropaleontology; Biostratigraphy; Depositional Environment; Paleobiogeography; Paleoceangraphy; Paleoclimate.

\section{Introduction}

Marine micropaleontology embraces studies on a diverse group of microfossils and modern microbiota that may be auto- or heterotrophic, planktic or benthic. The majority of marine microfossils own permineralized skeletons that are either composed of one or several common skeletal materials. For instance, in foraminifers, calcareous nannofossils, and coralline algae the skeletal material is composed of calcium carbonate; radiolarians, diatoms, silicoflagellates have skeletons composed of silica; skeletal material in acritarchs, chitinozoa, dinoflagellates, and scolecodonts is formed by organic compounds while conodont's skeleton is made up of calcium phosphate. The efficacy of marine microfossils in geosciences and allied fields is due to their small size, profuse occurrence in variable marine environments, and broad geographic distribution in sediments spanning almost the entire geological time scale i.e., from Precambrian to Recent times. Over the years, marine microfossils have been consistently found their utilization in the field of biostratigraphy, paleoenvironmental interpretations and in recording global ocean and climate change fluctuations. In recent times, much emphasis has been on the utilization of marine microfossils in seismic calibration(s), sequence stratigraphy and related research. Moreover, the study of marine microfossils is indispensable for the oil and gas sector, where marine micropaleontology is used as a tool to steer horizontal drilling of reservoirs for cost-effective production of hydrocarbons.

Keeping pace with global trends on the advancement of research on marine microfossils, the last few years/decades have witnessed remarkable contributions by micropaleontologists working on deep time (Jurassic-Neogene) as well as Quaternary sediments, in the Indian sector. In this context, the present review discusses (in detail) our present state

*Author for Correspondence: E-mail: prasad.van@gmail.com 


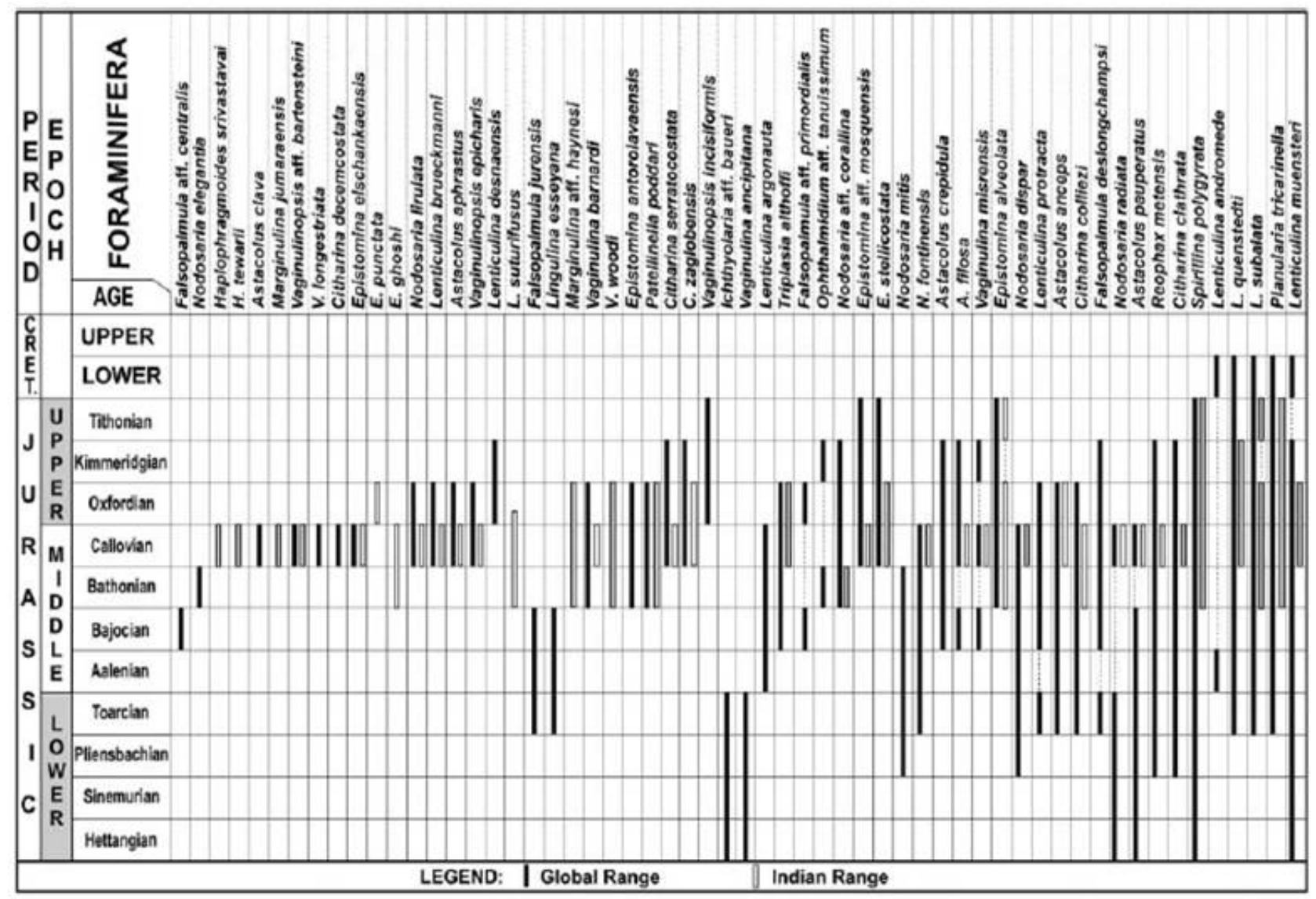

Fig. 1: Known global and Indian ranges of Jurassic foraminifera from the Dharang Member, Habo Formation, Habo dome, Kutch, Gujarat (after Talib et al., 2017)

of palaeoceanographic knowledge based on marine micropalaeontology studies in the Indian sector. Apart from discussing recent research utilizing biological proxies, the present article also showcases recent studies on nonbiological proxies (e.g., inorganic geochemistry, stable isotopic studies) that have been utilized in paleo-reconstructions along with biological proxies. Besides, we also discuss the active participation of Indian researchers in International research programs that include the International Ocean Discovery Program (IODP), International Geosphere-Biosphere Program (IGBP), Pliocene Arctic Climate Teleconnection (PACT). This aspect of discussion reveals another dimension (at par with international requisites in the field of micropaleontology) i.e., vital data has been generated by researchers to understand the dynamics of ocean currents, deep-sea processes and paleoclimatic variations. Numerous high-resolution records from the Arabian Sea, Bay of Bengal, Southern Ocean (Indian sector) and terrestrial record from India have provided a good understanding of ocean/land-climate variability, its dynamics and teleconnections in the context of current rapid change in global climate. IODP-India has also provided support to Indian scientists and researchers to carry out cutting edge geoscientific research through the IODP consortium from different oceanic regimes.

The great utility of marine microfossils for interpretation of the stratigraphic age and environment of deposition made them one of the most used tools from the Jurrasic to Neogene palaeontological research in India. The enhanced understanding and refinement of the biostratigraphic ranges of various microfossils are prerequisites for delineation of geological processes in the earth's history and primarily to facilitate better identification of signals of paleoenvironmental variability even up to the boundary of the global climate events. The Quaternary sediments were used for micropaleontological studies as a tool to decipher the past oceanic processes, 

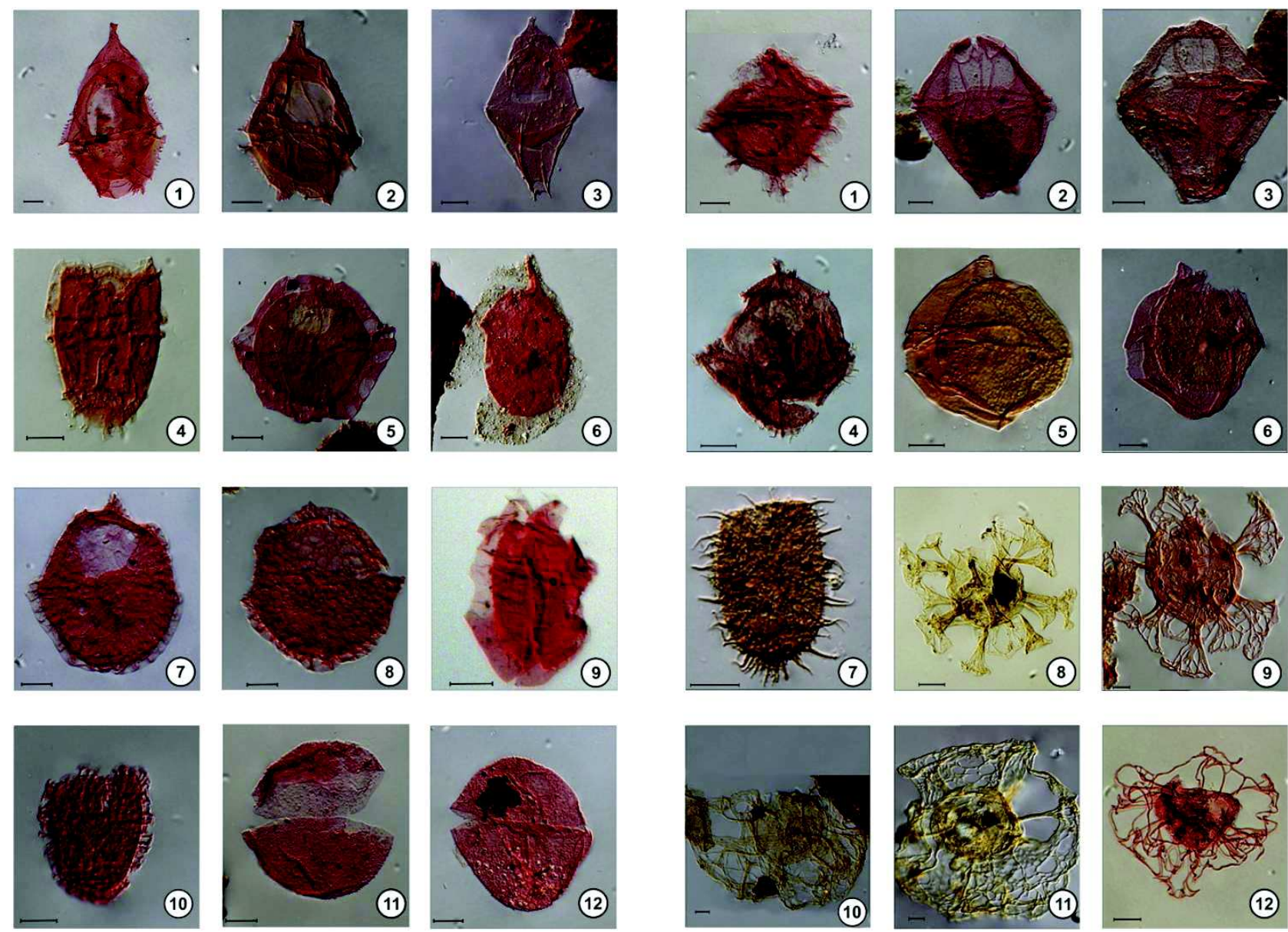

Fig. 2: Dinoflagellate cysts from Patasar Shale Member, Wagad Uplift, Kutch (after Riding et al., 2017)

productivity variations, past sea surface temperature and salinity, $\mathrm{CO}_{2}$ outgassing. Herein, significant contributions by Indian researchers in the field of marine micropaleontology during the years 2016 - 2019 have been summarized. This is to note that for a better understanding of the readers, the sections in the article have been categorized in a chronological order i.e., in a geological time scale (Jurassic to Quaternary) framework.

\section{Jurassic}

Callovian age foraminiferal assemblages systematically described from Chari Formation, exposed at Fakirwari Dome in Kutch envisaged shallow water, near shore, open marine middle shelf environment with frequently fluctuating shoreline. The assemblage was assigned to Indo-East African Province, located at the southern margin of the Tethyan realm and transitional between the Tethyan and the Antiboreal realms (Bhat et al. 2016). The other foraminiferal assemblage from the same region and time, described from Dharang Member of the Habo Formation, Habo Dome in Kutch suggesting that deposition took place in open marine conditions in a tectonically unstable middle to outer shelf, with a fluctuating shoreline (Talib et al. 2017). Riding et al. (2017) documented a well-preserved palynobiota including dinoflagellate cysts of Gondwanan (Australasian) affinity from the lowermost Patasar Shale Member of the Patasar Tank section, Wagad Uplift in the Kachchh Basin and dated Early Kimmeridgian age based on the Dingodinium swanense Interval Zone (Fig. 2).

\section{Cretaceous}

The foraminiferal study from Dherani Limestone Member, Ariyalur area in the Cauvery Basin proposed early Maastrichtian age based on the developmental 


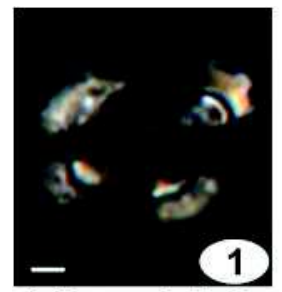

Arkhangelskiella cymbiformis

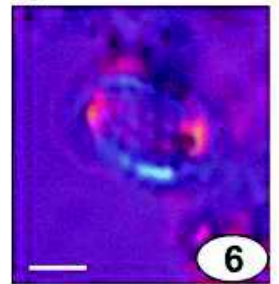

Cribrosphaerella ehrenbergii

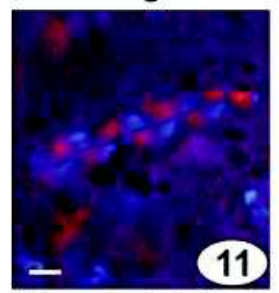

Microrhabdulus undosus

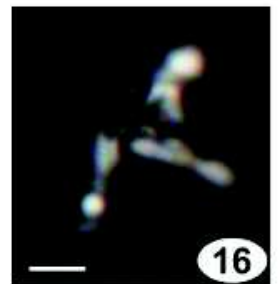

Micula prinsii

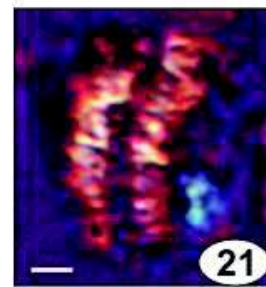

Nannoconus sp.

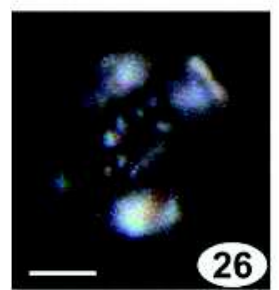

Retecapsa ficula

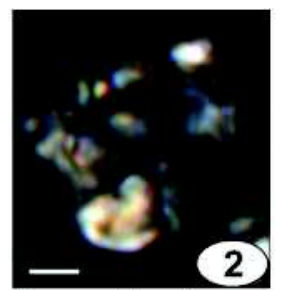

Braarudosphaera bigelowii

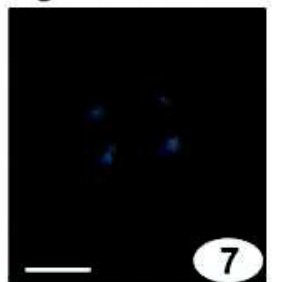

Cyclagelosphaera margerelii

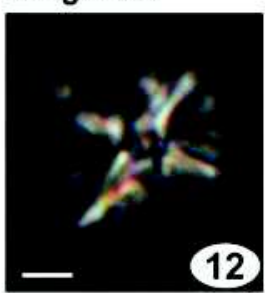

Micula concava

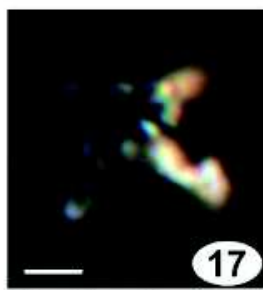

Micula prinsii

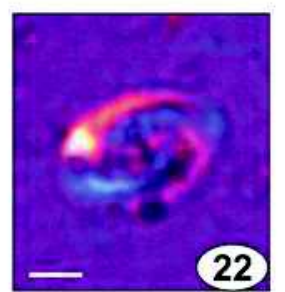

Placozygus

fibuliformis

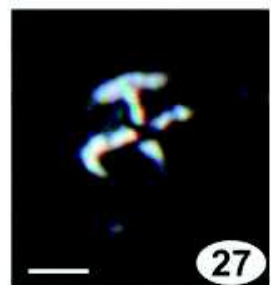

Staurolithites crux

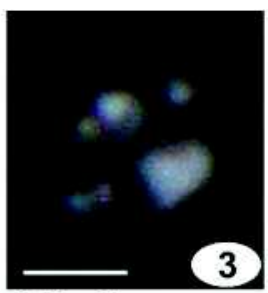

Calculites

obscurus

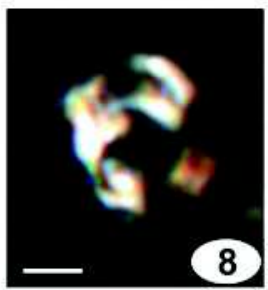

Cylindralithus

sculptus

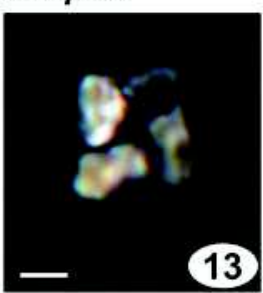

Micula murus

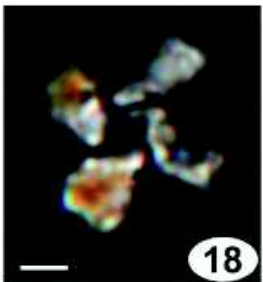

Micula prinsii

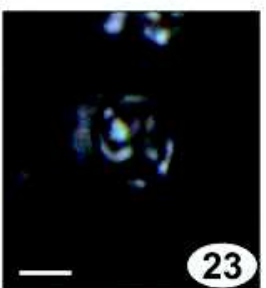

Prediscosphaera cretacea

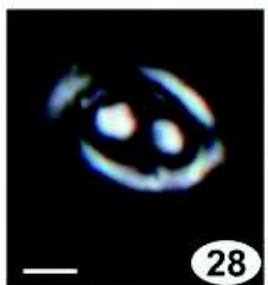

Tranolithus minimus

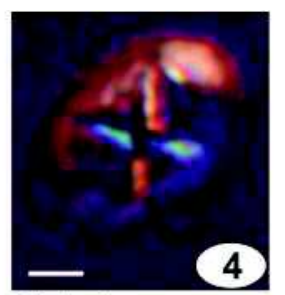

Chiastozygus

litterarius

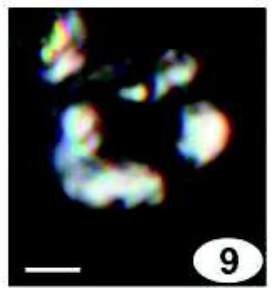

Eiffellithus sp.

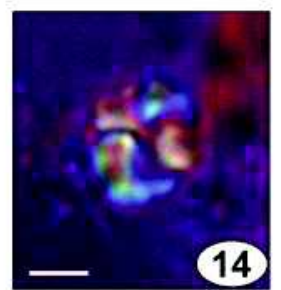

Micula praemurus

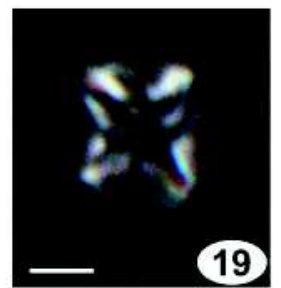

Micula

staurophora

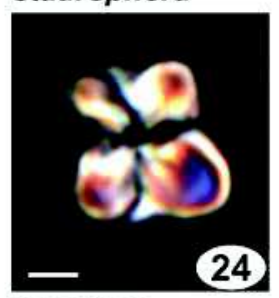

Quadrum

gartneri

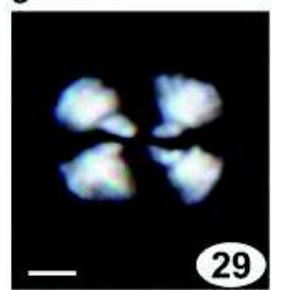

Watznaueria

barnesiae

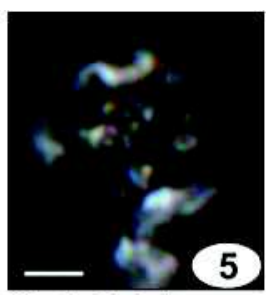

Cretarhabdus conicus

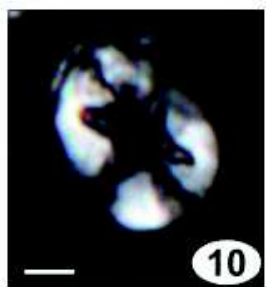

Eiffellithus turriseiffelii

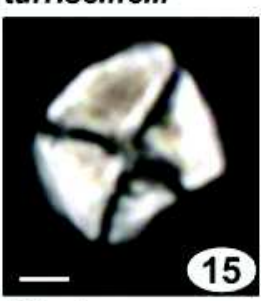

Micula premolisilvae

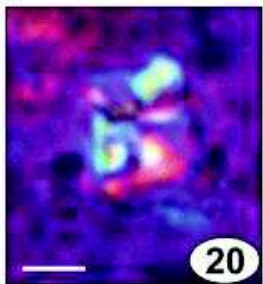

Micula

swastica

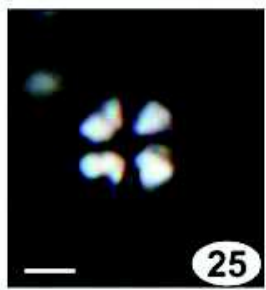

Radiolithus planus

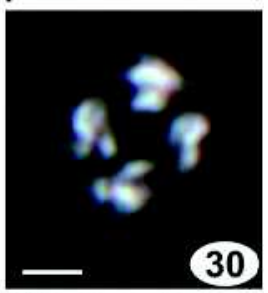

Watznaueria ovata

Fig. 3: Latest Maastrichtian calcareous nannofossil assemblage from Syndai Village, Meghalaya (after Singh 2018) 


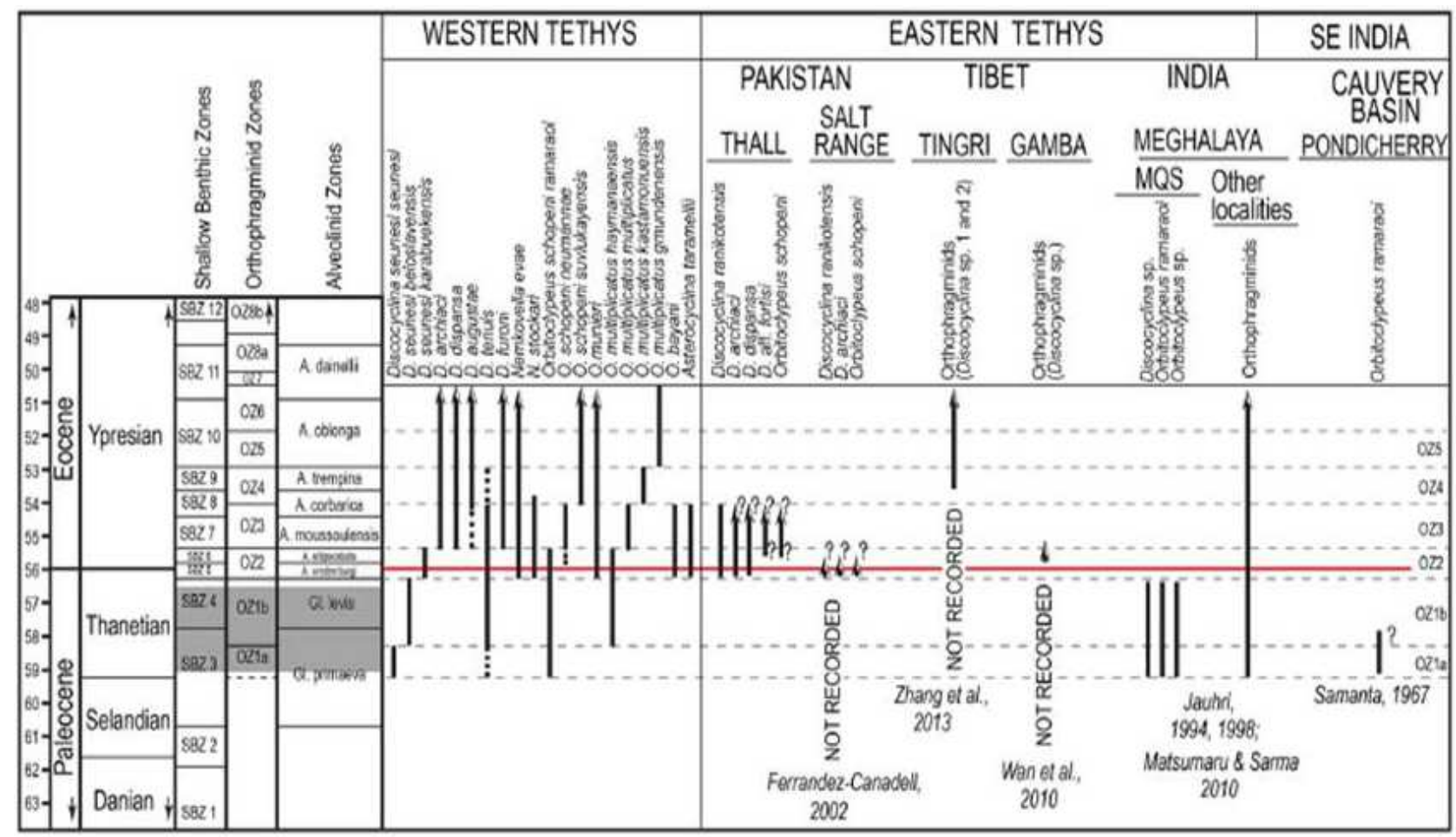

Fig. 4: Records of Orthophragminids in the Paleocene and Paleocene-Eocene boundary in Tethys and SE India (after Ozcan et al. 2018)

state of Lepidorbitoides, the occurrence of Siderolites and absence of typical Campanian Larger Benthic Foraminifera (LBF) (Malarkodi et al. 2017). The recorded data was also used to assess the phylogenetic stage of the genus by evaluating them with the evolutionary model of Lepidorbitoides from the Western Tethys and with Maastrichtian paleobiogeography of the genus.

In the northeastern region, Singh (2018) conducted a study from the outcrop section near Syndai Village, Meghalaya and recorded the latest Maastrichtian calcareous nannofossils belonging to Micula prinsii Zone. The distribution pattern of calcareous nannofossils (Fig. 3) has been linked to climatic variability within the Micula prinsii Zone and confirmed an additional warming pulse before K-Pg boundary in Tethyan province. The paleoenvironmental studies from the same region, in Um Sohryngkew River section, Meghalaya provided organo-chemical evidence of incidence of "regional fire" which was possibly responsible for stepwise disappearance of planktic foraminifers in upper Maastrichtian biozones (CF4-CF3) and migration of some forms out of warm water environment (Pal et al. 2018). Among the various other causes of late Maastrichtian warming, they presumed the regional fires to be one of the factors.

From the western Indian region, Singh and Rai (2017) carried out calcareous nannofossil biostratigraphy from $795 \mathrm{~m}$ thick subsurface Cretaceous succession (depth range 1104-1899 m) from Tanot area, Jaisalmer Basin. Detailed systematic description of 222 nannofossil species belonging to Late Albian to Early Maastrichtian age has been produced in this study.

Timing of angiosperm diversification was addressed by Prasad et al. (2018) through a palynological study from borehole sediments of Infratrappean deposits in the Ashtona Village, Yeotmal District, Maharashtra. The Cretaceous paleovegetation, paleoecology, depositional environment and paleogeography of central India before Deccan volcanism has been discussed based on a rich assemblage of pollen-spore and dinoflagellate cysts. Furthermore, a shallow marine embayment in central India during the late Maastrichtian, which 


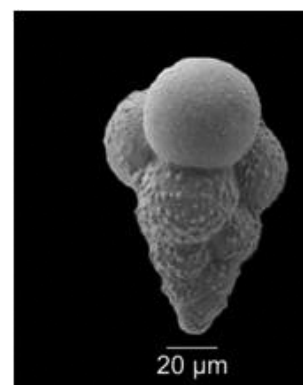

1.

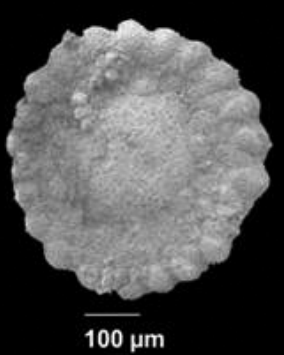

6.

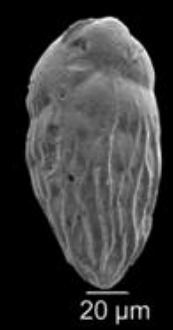

11.

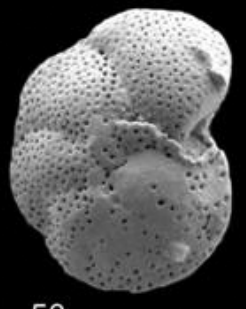

$50 \mu \mathrm{m}=$

16.

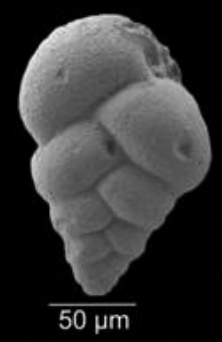

2.

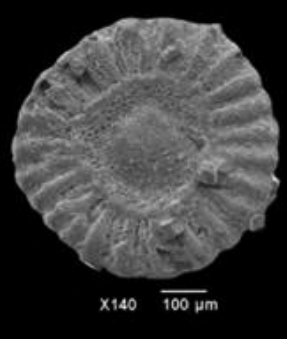

7.

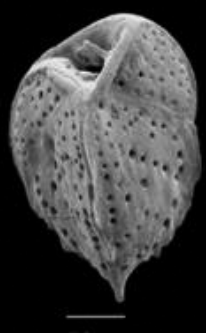

$50 \mu \mathrm{m}$

12.

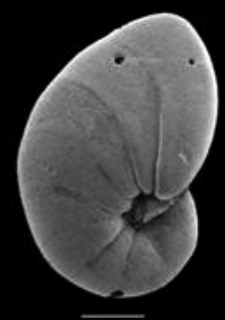

$50 \mu \mathrm{m}$

17.

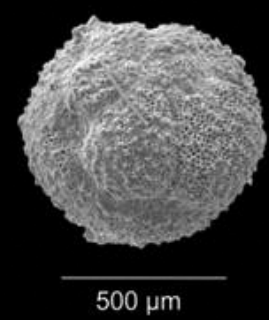

3.

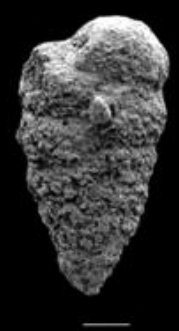

$100 \mu \mathrm{m}$

8.

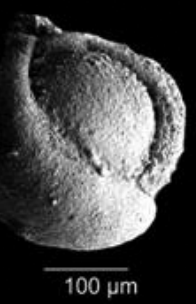

13.

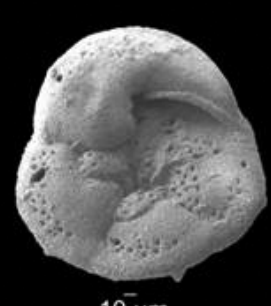

18.

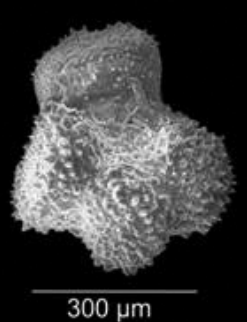

4.

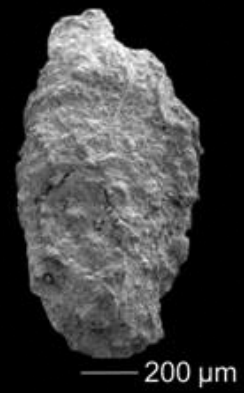

9.
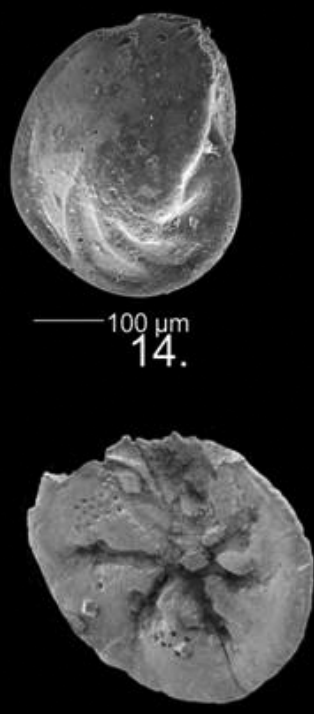

$\overline{100 \mu \mathrm{m}}$

19.

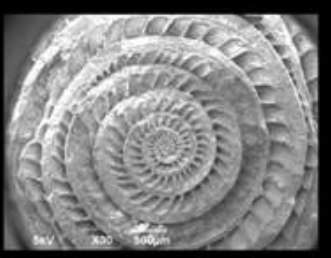

5.

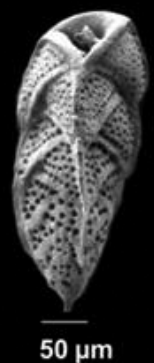

10.

Fig. 5: The foraminiferal assemblage from the Panandhro and Matanomadh lignite mines (after Khanolkarand Sharma 2019)

extended from the east coast through the Godavari rift zone, was envisaged. The study supported the Out-of-India hypothesis.

\section{K/Pg Boundary}

A planktic foraminiferal biostratigraphic study from the continuous upper Maastrichtian- middle Danian shelf successions in Meghalaya have provided planktic foraminiferal biozones at a finer resolution (Mukhopadhyay 2016). The effect of basin instability on planktonic foraminiferal successions and sea-level changes during the late Maastrichtian to early middle Danian (K-Pg transition) has been analyzed to delineate the depositional environment. 

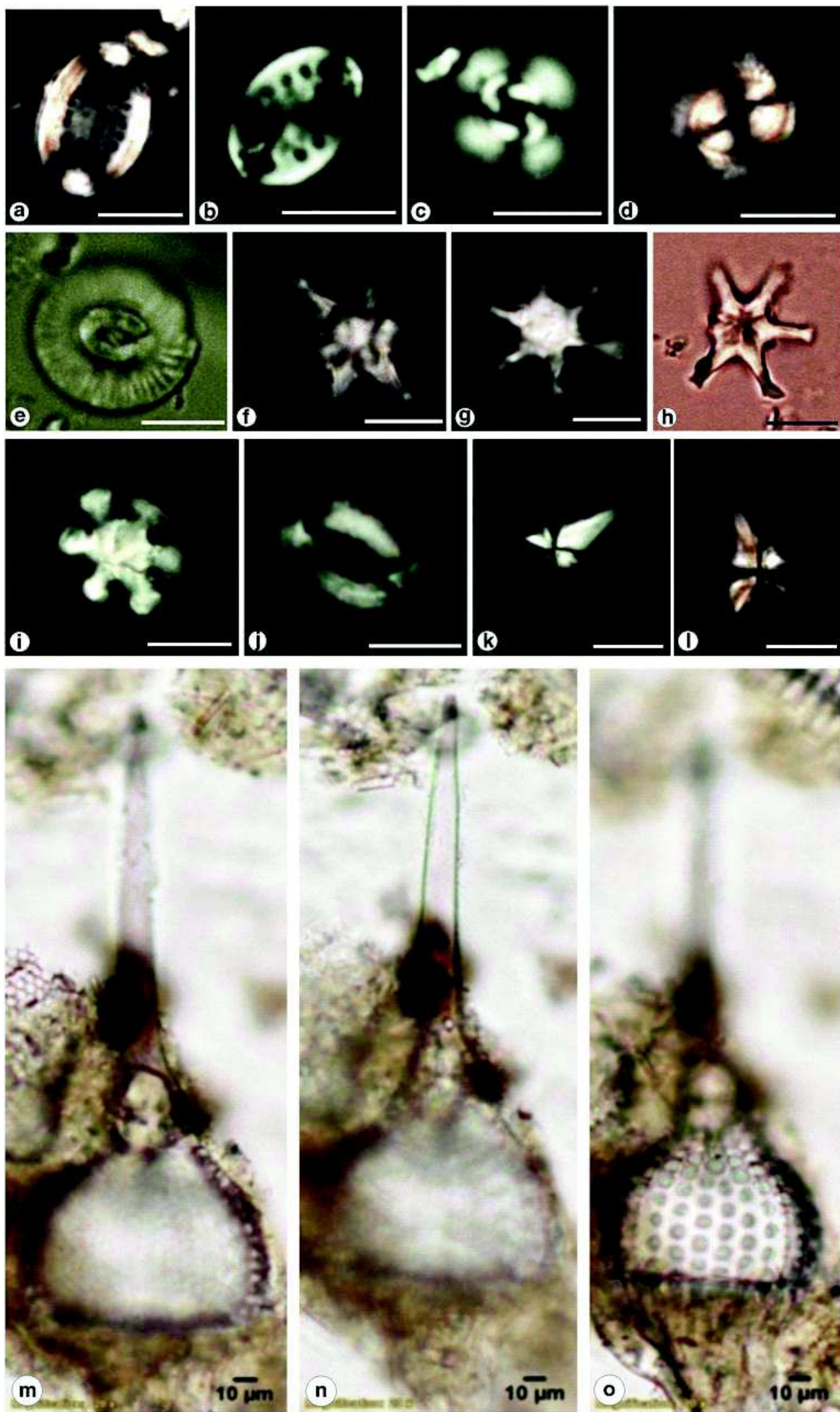

Fig. 6: Commonly occurring calcareous nannofossils and radiolarians from Kalapathar Section, Havelock Island (after Chakraborty et al. 2018) 


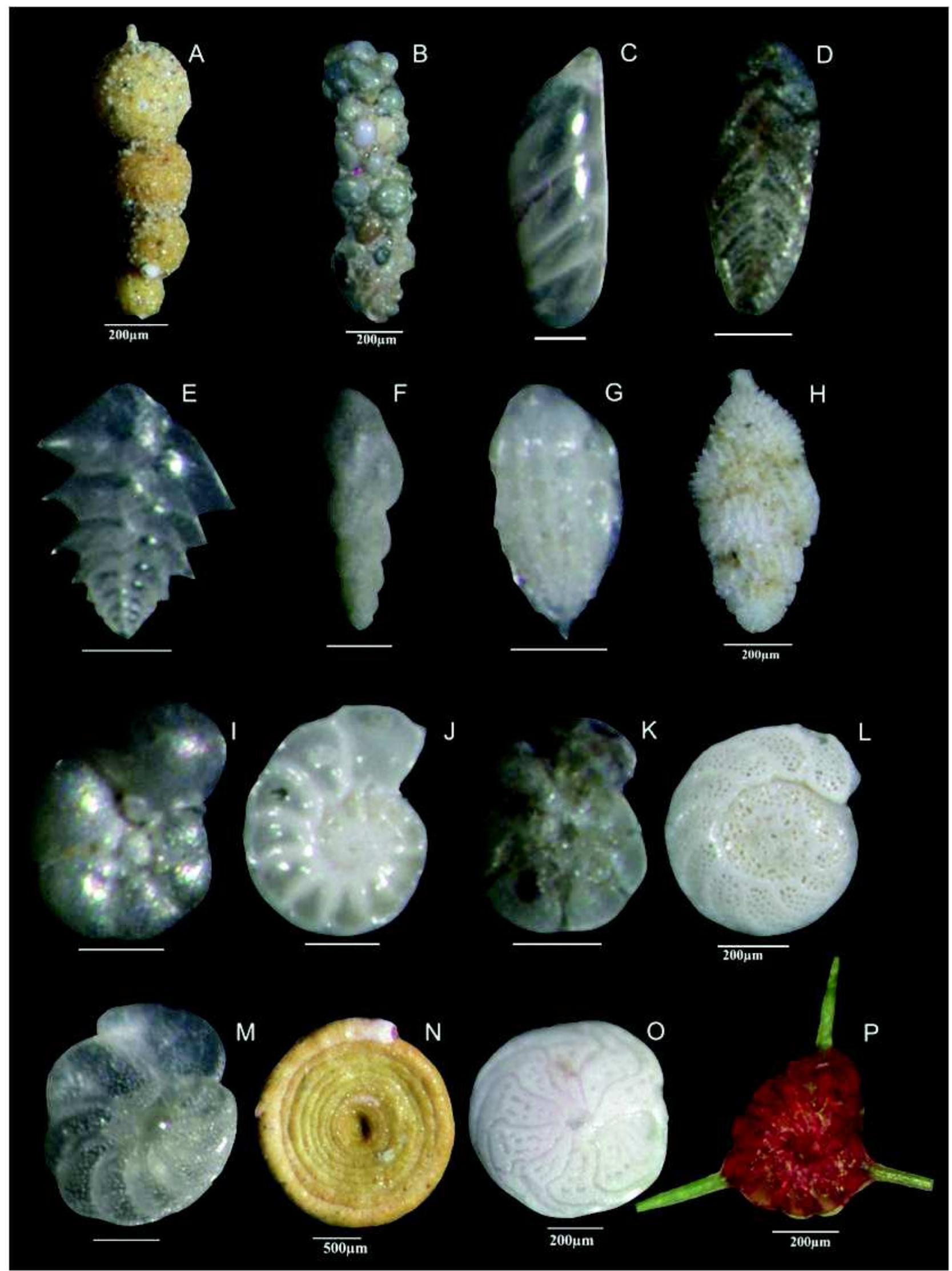

Fig. 7: Benthic foraminiferal morpho-groups from the shelf and slope of the central-western Bay of Bengal (after Suokhrie et al., 2018) 


\section{Paleogene}

Palynofacies analysis from two Lakadong Limestone sections, Dohsniang (Kurtinsiang) (KPL) and Laitmowksing (LTL) from Khasi Hills (Meghalaya) showed a cyclic pattern in the organic matter types, linked to the higher-order sea-level changes. The sections were dated as late Paleocene based on the characteristic larger benthic foraminiferal assemblages belonging to the Tethyan Shallow Benthic Zones (SBZ) 3(Gogoi et al. 2018). A multi-proxy study based on grain size, physical sedimentary structures, biogenic structures, palynological, geochemical and organic carbon isotopic analyses have been carried out on upper Paleocene-lower Eocene coal-bearing shallowmarine succession from Jathang, East Khasi Hills, Meghalaya (Prasad et al. 2018). The study envisaged that the succession was deposited in a low-energy, coastal marsh-bay complex with reduced duration of the dry period during the latest Paleocene-earliest Eocene, due to a more active hydrological cycle in the paleo-equatorial region. Özcan et al. (2018) established a systematic, biostratigraphic and paleobiogeographical framework for orthophragminids from late Paleocene Lakadong Limestone in Meghalaya (Fig. 4). The Paleocene and Eocene orthophragminids records from India and Pakistan suggested that Orbitoclypeus is the only orthophragminid in the Paleocene of the eastern Tethys whereas Discocyclina first appears in early Eocene times, being mainly represented by endemic taxa confined to the Indian subcontinent. Facies change in the Mawmluh Quarry Section from a marine to the continental setting within SBZ 4 corresponds to the oldest record from the Indian plate in the Paleogene, which may be linked to the flexural uplift of the passive margin of the Indian plate, marking the onset of the collision of the Indian and Eurasian plates.

In the same area, the dominance of PaleoceneEocene coralline alga Distichoplax recorded from multiple carbonate sections outcropping in Mawmluh. The study suggested the intertidal to subtidal zones of the shallow-marine ecosystems about high hydrodynamic conditions in an oligo-mesotrophic nutrient regime. Their gradual extinction may be linked to the climate adversities like the Paleocene-Eocene Thermal Maximum (PETM) and biotic pressures like the Larger Foraminiferal Turnover (LFT) (Sarkar 2018). Sarkar (2019) studied paleoecological characteristics of Late Thanetian (SBZ 4) benthic foraminifera Haymanella elongata and Keramosphaera iranica from the same successions and depicted that both the forms were sensitive to the hydrodynamics in shallow-marine environments. Sarkar and Rao (2018) studied coralline red algae and larger benthic foraminifera from Late Paleoceneearliest Eocene carbonate succession of Sylhet Limestone platform deposits outcropping on the JowaiBadarpur Road in the Jaintia Hills Meghalaya and conceptual food web and trophic-level structure envisaged for the Lakadong Limestone Paleocommunity. The microfacies analysis of LBF from the Middle Eocene sediments of Prang Formation, Sylhet Limestone Group in Meghalaya suggested deposition in an oligotrophic nutrient regime from restricted lagoonal to proximal/middle outer shelf environment. The reason for the dominance of LBF genera with the scarcity of corals has been attributed to the biotic response to events like MECO which triggered warming episodes (Sarkar 2017a).

A conceptual paleoenvironmental model based on early Eocene calcareous algae and benthic foraminifera from the Umlatdoh Limestone succession, Meghalaya has been showcased various facies gradients, bathymetry levels, and shelf zones (Sarkar 2016). Humane et al. (2017) reported early Eocene Halimedacean and Udoteacean algal assemblage from shallow marine subsurface Sylhet Limestone Formation of the Bengal Basin, India which is closely comparable to the Paleogene Halimedacean and Udoteacean algal elements of Morocco and Egypt. They also explained that the association of Halimedacean and Udoteacean algae with Dasycladalean elements indicates that the deposition took under shallow, warm, tropical, open lagoonal to shelf environment at a depth of 5-6 m below low tide level with Tethyan affinity. A brief overview of the fossil coralline red algae recorded from the different sedimentary basins of India, their paleoecological applications have been discussed by Sarkar (2017b). Emphasizing studies on coralline red algae, the drawbacks and prospects of paleoalgological studies in India pertinent to significant aspects such as paleoecology, paleoenvironmental reconstructions, climate dynamics and extinction episodes are also discussed.

Singh et al. (2016) reported well-preserved 

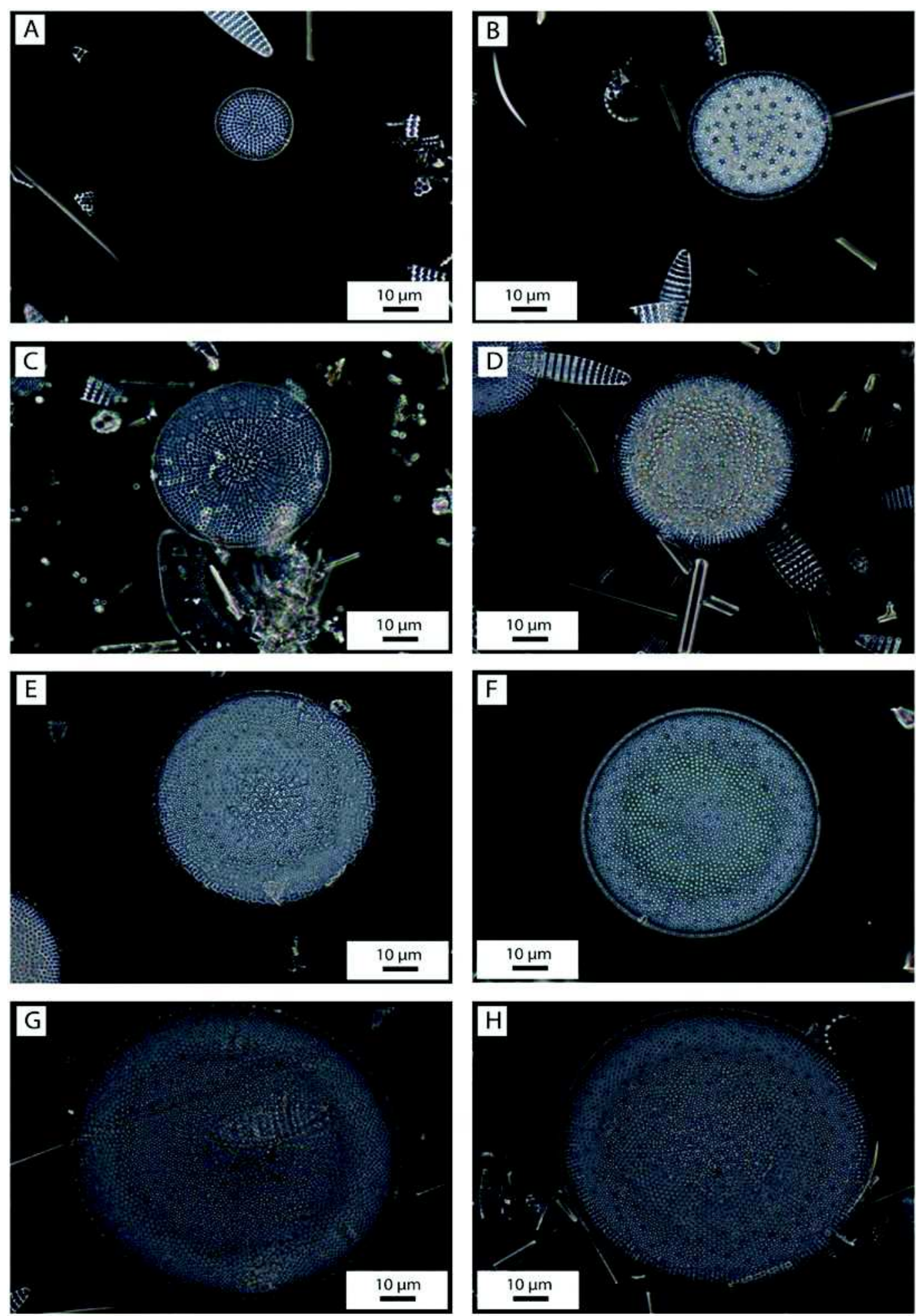

Fig. 8: Light micrographs of Thalassiosiralentiginosa showing valve size variability (small to large-sized - A to H) from surface and down-core sediments from the southern ocean (after Shukla et al., 2016)

Priabonian age calcareous nannofossils from the Rewak Formation exposed along the Siju-Rewak road section, West Garo Hills, Meghalaya. Based on the assemblage, they suggested that the deposition took place in a hemipelagic, nearshore, warm water environment. Singh et al. (2018) highlighted 

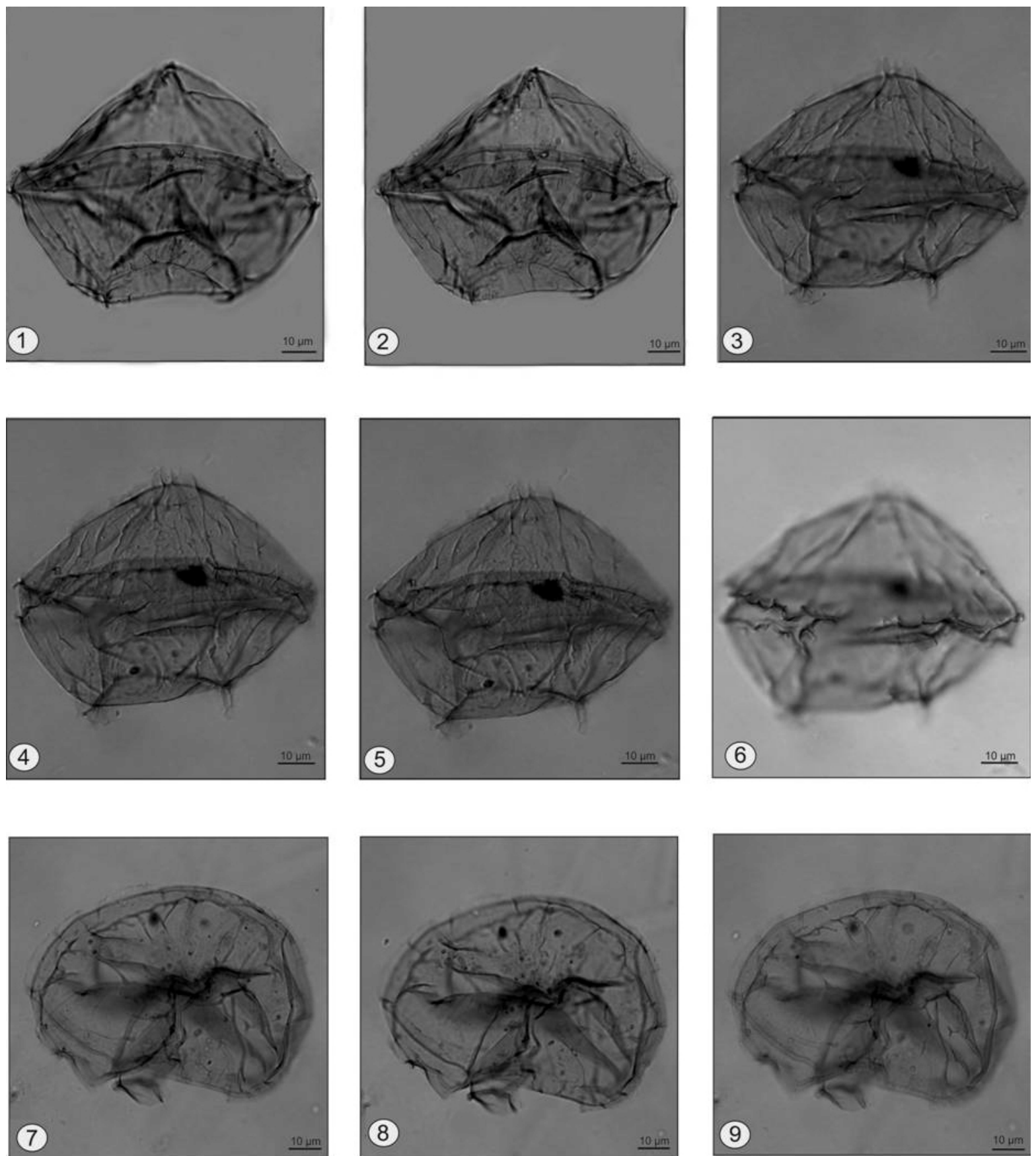

Fig. 9: Cristadinium striatiserratum reported from the modern sediments of the northern Indian Ocean (after Uddandam et al., 2018)

Paleogene events in the Manipur region on the basis of fossil evidences and erected three biostratigraphic zones ranging in age from late Paleocene-early Eocene (Thanetian-Ypresian) and suggested shallowing up in depositional environment from Upper Disang Formation to Barail Group.
In the western Indian region, based on an integrated study of sedimentary structures (including paleokarst and paleosols), carbonate microfacies and micropaleontological characteristics, two depositional sequences (having cyclicity) were depicted in the Eocene succession of Kutch. The cycles of Sequence-I were of low amplitude, low frequency, 
and limited to inner shelf having cyclicity of $1.2 \mathrm{Myr}$ while Sequence-II comprises high frequency and higher amplitude cycles on mid-shelf settings having cyclicity of $77 \mathrm{Kyr}$ (Saraswati et al. 2016a). Based on the biostratigraphy of planktic foraminifera and LBF from the Eocene succession of Kutch, Saraswati et al. (2016b) estimated hiatuses of $\sim 7 \mathrm{Myr}$ between the Deccan Traps and Naredi Formation, $\sim 7 \mathrm{Myr}$ between Naredi Formation and Harudi Formation and $\sim 4 \mathrm{Myr}$ between Fulra Limestone and Maniyara Fort Formation. They also reported no evidence of Paleocene marine sediments in on-land Kutch. The test morphological studies of Bartonian Orthophragminids of the Indian subcontinent facilitated the erection of two new species Discocyclina kutchensis and D. sulaimanensis possibly representing endemic foraminiferal fauna confined to Indo-Pakistan region and are important for Paleobiogeographic studies (Özcan et al. 2016). Khanolkar \& Saraswati (2016) reported an atypical planktic foraminifer, bearing close resemblance with Orbulinoides from the restricted marine Middle Eocene (Bartonian) succession of Kutch, western India although taxon was still unnamed and open for nomenclature. Saraswati et al. (2017) examined the earliest reticulate Nummulites forms occurring in the Bartonian succession of Kutch and carried out a detailed biometric analysis to distinguish them and inferred that three reticulate species of Nummulites possibly evolved from $N$. acutus in Zone P14.

A combined palynological and stable carbon isotope $\left({ }^{13} \mathrm{C}\right)$ investigation from the lignite sequence at Panandhro, Kutch assigns an early Eocene (Ypresian) age to the lignitic succession based on dinoflagellate cysts and associated spore-pollen assemblage. Furthermore, a pronounced negative Carbon Isotope Excursion (CIE) of about 2.7\%, correlatable to the Second Eocene Thermal Maximum (53.7 Ma) hyperthermal event, has been noticed. It was concluded that there is no significant age difference between the lignite deposits of the Kutch and Cambay basins Agrawal et al. (2017). Saraswati et al. (2018) thoroughly reviewed the foraminiferal biostratigraphy of the Paleogene successions of Kutch and discussed the development in the stratigraphy of Kutch considering taxonomic revisions of the LBF and the refined shallow benthic zonations (SBZ). It is suggested that climate played a major role in building up the Paleogene stratigraphic succession of Kutch, the carbonates formed during the warming intervals and the stratigraphic gaps were in the intervening cooling periods. Khanolkar et al. (2017) discussed the ecological response of foraminifers across the Middle Eocene Climatic Optimum (MECO) warming event from carbonate samples from Harudi and Fulra Limestone formations of Kutch. The study reveals that warming in middle Eocene commenced with high precipitation and eutrophy, but soon warmer and oligotrophic conditions prevailed that provided an optimum environment for larger benthic foraminifera to flourish and form the major carbonate platform. Khanolkar and Sharma (2019) have addressed the similarities and differences observed in the paleodepositional and paleovegetational conditions from the Cambay, Kutch and Barmer basins during the tropical climate of the Early and Middle Eocene (Fig. 5). For this, they have used an integrated approach by quantitatively analyzing various microfossil groups (foraminifera, spores- pollen, dinoflagellate cysts and fungi). Their results suggested the presence of overall tropical vegetation during Early and Middle Eocene in western India.

Furthermore, rainforest elements along with mangrove vegetation have recorded from Cambay and Barmer basins which were deposited in the marginal marine setting. In the Kutch mine sections, the bloom in triserial planktic foram and RBFs, low diversity and the presence of atypical planktic foraminifera are indicative of eutrophic and stressed conditions of deposition. In the same area, Khanolkar and Saraswati (2019) investigated the foraminiferal biofacies of shallow marine successions from a paleotropical site in western India (Kutch Basin) to understand the paleoclimate and its impact on the ecology of foraminifera. The results indicated that EECO and MECO did not harm shallow marine foraminifera, and mainly the larger benthic foraminifera attained high diversity, high abundance, larger size and broader latitudinal distribution in the middle Eocene.

Banerjee et al. (2018) presented paleodepositional and paleobathymetric interpretations for Middle Eocene Fulra Limestone and Oligocene Maniyara Fort formations of Kutch using benthic foraminifera in combination with a lithological association, sedimentary structures, and early diagenetic features. They erected six carbonate facies 
from the Fulra Limestone indicate a depositional spectrum ranging from bar-lagoon to mid-ramp depositional conditions and four carbonate facies of the Maniyara Fort Formation represents deposition within the inner ramp setting in bar-lagoon and patchreef environment. Broadly, the depositional setting of the Paleogene carbonate in Kutch resembles Eocene platform deposits in the circum-Tethys belt.

The global distribution pattern of Oligocene times corals from Maniyara Fort Formation, Kutch, and other records of the world had suggested strong specific endemism whereas large generic panedemism and had climatically controlled circumtropical distribution more or less similar to present day. The paleobiogeographical analysis revealed a strong Tethyan affinity of most of the province, suggesting a trans-Atlantic surface current and passages through the sea between the two American continents in Oligocene times (Sinha and Halder 2018). Less et al. (2018) performed a morphometric analysis of the nummulitids and lepidocyclinids from the Oligocene succession (Maniyara Fort Formation) of Kutch and compared them with the assemblages of Western Tethys. In the absence of planktonic foraminifera and calcareous nannoplankton data, Sr-isotope stratigraphy was applied as an independent tool for correlation and chronostratigraphic calibration between the Kutch and Western Tethyan Oligocene larger benthic foraminifera assemblages. Lumpy Clay Member of Maniyara Fort Formation is considered as unfossiliferous in terms of foraminifers and was dated on the basis of foraminiferal assemblages of underlying Basal and overlying Coral Limestone members. Verma and Singh (2019) conducted a study to resolve the discrepancy in the precise age of this strata and assigned Middle Rupelian ( $\sim 31 \mathrm{Ma})$ age for the Lumpy Clay Member exposed at Bermoti Village, in Kutch based on dinoflagellate cysts and calcareous nannofossils.

Late middle Eocene-early Oligocene planktonic foraminifera was documented by Kalia and Sahu (2018) from the DSDP Sites 219 in the Arabian Sea, and site 237 in the western tropical Indian Ocean. MECO event was recorded at the Site 237. Sudden warming was reported in the Zone E12 with the extinction of Acarinina bullbrooki and A. topilensis. Whereas, a drop in temperature close to the end of MECO was marked by extinction of
Globigerinatheka kugleri, G. euganea, Morozovelloides coronatus, $M$. lehneri, and $O$. beckmanni. The change from the greenhouse to the icehouse world have been expressed by the composition and pattern of change in the planktonic foraminiferal assemblages of the zones E13 to O2 from both the sites.

Further from southern India, Mukhopadhyay (2018) recorded conjoined and aberrant test of Nummulites aff. $N$. acutus with minute biotic bodies from the subsurface middle Eocene sediments of South Pondicherry, Cauvery Basin. The study indicates gamontogamy of plastogamy type of sexual reproduction by the adult individuals of Nummulites aff. $N$. acutus to generate offspring as microspheric forms. Two distinct foraminiferal assemblages were recorded from the basal and top part of the Paleocene sequences in Andaman Islands by Koley et al. (2018). They suggested deep water depositional environment prevailed during the Lower Paleocene and shallow marine high energy condition thrived during the Upper Paleocene period.

Rai (2018) summarizes available records of nannofossils in Paleogene sedimentary successions from several sedimentary basins of India and also pointed out the gaps which can be taken into account in the near future. Raju (2018) presented an overview of the Paleogene stratigraphy of India with special emphasis on deposits and major geological events that occurred during Paleogene time in different basins of India viz. Himalayan foreland, NE Region, Andaman, West Bengal, Mumbai offshore, Cambay, Kutch and Jaisalmer.

\section{Neogene}

Banerjee et al. (2017) presented the first detailed $\delta^{13} \mathrm{C}$ and $\delta^{18} \mathrm{O}$ records of surface and deep-dwelling foraminifera from ODP site 758 in the Northeast Indian Ocean. A series of climatic events including (a) Mid Miocene Climatic Optimum (17-15 Ma), (b) Monterey excursion (17-14 Ma), (c) East Antarctica Ice sheet formation (13.8 Ma), (d) Initiation of Indian Summer Monsoon with waning of Antarctica Ice sheet (12.3-10.4 Ma), and (e) evidence of a cooling event (10.2-9.6 Ma) have been depicted in the study. A significant decrease in $\delta^{13} \mathrm{C}$ at $\sim 10.2 \mathrm{Ma}$ was indicative of a complete re-adjustment of the carbon cycle after the Monterey excursion and export of the North 
Atlantic Deep Water (NADW) towards the southern Ocean giving rise to Circumpolar Deep Water (CDW). A good correlation between the South Pacific, Indo Pacific, and Northeast Indian Ocean cores suggests that the strong westerly Indian Ocean current (MIOjet) linked these Oceans from $14 \mathrm{Ma}$.

Singh and Raju (2018) presented a study based on the phylogenetic evolution of miogypsinids of Burdigalian age from Bombay offshore. They used morphometric characters together with their biostratigraphic ranges and facies relationships as a vibrant tool for the study of shallow-water carbonate deposits, which are essential for a hydrocarbon exploration point of view. Integrated biostratigraphy from the Havelock Island was carried out by Chakraborty et al. (2018) based on multiple microfossils (diatoms, calcareous nannofossils, radiolarians) from the outcrop exposed in Vijaynagar Village near Kalapathar Beach. The recorded microfossils suggested an age range of $\sim 16.4$ to $\sim 15.0$ Ma (early-middle Miocene) and the deposition took place in a deepwater environment under the influence of MMCO event. Biofacies analysis was performed on late middle Miocene (Serravallian) algalforaminiferal assemblages and carbonate deposition from the Hut Bay section of the Little Andaman Island. The biogenic assemblages indicate meso-oligotrophic, tropical shelf environmental settings with shallow to mildly deeper bathymetric levels (Sarkar et al. 2016).

Rai et al. (2017) used different indices of the diversity of planktic foraminifera to demonstrate the Pliocene Indonesian Through Flow (ITF) changes in the eastern subtropical Indian Ocean. The strong influence of warm ITF waters due to broad and open seaway until the end of early Pliocene increased the SST and depth of thermocline in the Leeuwin current area. The significant decline in faunal diversity between $\sim 3.5$ and $3 \mathrm{Ma}$ is suggested to be in response to the fall in SST and increased surface water productivity due to reduced influence of ITF demarks the constriction of Indonesian seaway.

\section{Quaternary}

Several new proxies have been used in micropaleontology from different regimes for Quaternary studies by Indian Scientists to understand the paleomonsoonal and paleoclimatic changes over time. Kiran Kumar \& Ramesh (2017) compiled recent high resolution foraminiferal $\delta^{18} \mathrm{O}$ data from the eastern Arabian Sea cores and adopted the explanation of steady strengthening of the summer monsoon during the Holocene. Naik et al. (2017) report enhanced productivity in the south-eastern Arabian Sea during MIS 3 whereas the Last Glacial maxima (LGM) are characterized by an abrupt fall in productivity, with oxygen-depleted waters. A variable relationship between the south-eastern Arabian Sea and the North Atlantic interventions through oceanic or atmospheric circulation account for the contrasting productivity during Heinrich stadial (HS) event 1 and 2. The global $\delta^{13} \mathrm{C}$ minimum during the last deglaciation was associated with the weak monsoon interval during HS-1 and reduced productivity. Saraswat et al. (2016), reported Mid-Holocene Climate Transition based on a major shift in evaporation-precipitation (E-P), accompanied by a net cooling of SST synchronous with a change in surface productivity during the midHolocene. The MHCT coincides with decreasing lowlatitude summer insolation, perturbations in total solar intensity and an increase in atmospheric $\mathrm{CO}_{2}$. Naik (2016) also reconstructed SST in core AAS9/21 from the eastern Arabian Sea on two sets of planktonic foraminifera. The $\mathrm{Mg} / \mathrm{Ca}$ values using G. ruber sensustricto are seen to be higher during the Holocene whereas during the deglaciation, reconstructed SST from $G$. ruber sensu-stricto and sensu-lato accounts for stronger upwelling. Singh et al. (2016) presented a multi-proxy record from a gravity core from the ocean upwelling area in the western Arabian Sea. Based on the analysis, three intervals of increased Southwest Monsoon Mode (SWM) were inferred at $\sim 16$ to $12 \mathrm{ka}$ (SWMI-I), $\sim 10 \mathrm{ka}$ (SWMI-II) and $\sim 8.2-$ $8.0 \mathrm{ka}$ (SWMI-III). Two intervals of increased Northeast Monsoon Mode (NEM-winter monsoon) have also observed around 19-17 ka and NEMI-II $(\sim 8.0-5.4 \mathrm{ka})$.

Das et al. (2017) discussed the development and intensification of the oxygen minimum zone (OMZ) in the north-western Arabian Sea during the Holocene from records on benthic foraminifera and suggested replacement by oxygenated southern sourced Sub-Antarctic Mode and Antarctic Intermediate Waters, with oxygen-deficient Red Sea Water from the north during the middle Holocene. Naik and Naik (2018) suggest that the $\mathrm{CO}_{2}$ outgassing noticed during deglaciation makes the Arabian Sea, an interesting region to understand if the outgassing 
occurred from the deeper waters and hence led to any rise in deepwater $\left[\mathrm{CO}_{3}{ }^{2-}\right]$. The study from Verma et al. (2018) includes the cores from the lower boundary of the present-day OMZ offshore Goa. This study reports the abundance of benthic foraminifera with planoconvex tests during the cold HS, with oxygenated sea bottom due to better ventilation and weaker OMZ. Simultaneously, the benthic foraminifera having tapered/cylindrical tests dominate during the LGM and the Holocene (5 8 ka BP), suggests an oxygen-depleted benthic environment. Singh et al. (2018) published a planktic foraminifera abundance and SST based record to decipher past changes in sea-surface hydrographic conditions from the southeastern Arabian Sea core. The study suggests that intensified winter winds during 17.5-23.5 ka BP, resulted in nutrient injection into surface waters and eutrophic conditions, mainly through deep vertical mixing and moderate upwelling; and reduction in winter wind intensity caused stratification characterized by the high tropical SST since $17.5 \mathrm{ka}$ BP.

Paleoclimatic studies using multi-proxy records from the NE Arabian Sea revealed the variations in the shelf environment of the western continental margin of India (Azharuddin et al., 2017; 2019). The periodicities in the multi-proxy record consisted of similar cycles, which also match with previously reported solar insolation influenced SWM and other global and regional cycles. The observations suggested that the solar insolation has been a leading factor responsible for the SWM trends during the Holocene, which may have further influenced the productivity, regional sea-level fluctuations and depositional conditions in the north-east Arabian Sea. In the western Arabian Sea oxygen isotopes data from planktic foraminiferal species (G. sacculifer) studied by Naidu et al. (2019) documented an increase in deglacial sea surface salinity seasonality attributed to the increase in winter evaporation and reduced monsoonal rainfall in contrast to the Holocene. Results shows a common winter-dominated SST signal in the Arabian Sea and Greenland during the last glacial period and the North Atlantic link to the Indian Ocean SST. Satpathy et al. (2019) from the eastern Arabian Sea (IODP site U1457) reported two distinct regimes of monsoon-induced changes in upper water structure. The period 1.85-2.7 Ma was attributed to an overall weaker South Asian/Indian winter and summer monsoon circulations and the period between 1.55 $\mathrm{Ma}$ and $1.65 \mathrm{Ma}$ was characterized by enhanced eutrophication of the mixed layer triggered by intensified winter monsoonal winds.

Khare et al. (2017) performed cluster analysis on benthic foraminiferal assemblage from 32 stations off the Mangalore-Cochin sector to study the ecological preferences and effect of depth on external test morphology. They grouped the foraminiferal distribution into three clusters and attributed the observed morphological changes to the sediment turbulence. Singh et al. (2018) document the vertical distribution of living benthic foraminifera along a depth gradient $(58-2750 \mathrm{~m})$ in the Gulf of Mannar to understand the sediment depth containing representative living assemblages of foraminifera populations and associated ecological parameters for their abundance. Singh et al. 2017 published a pteropod based record of factors affecting the Aragonite Compensation Depth (ACD) in the Arabian Sea. The study suggests that the ACD in the eastern Arabian Sea lies at $\leq 525 \mathrm{~m}$ water depth. The study also infers that the low dissolved oxygen coupled with the organic matter content in the sediments appears to favour better pteropod preservation in the eastern Arabian Sea.

Gebregiorgis et al. (2016) discuss the south Asian summer monsoon variability during the last $\sim 54$ kyrs inferred from $\delta^{18} \mathrm{O}$ of seawater (D $\left.\delta^{18} \mathrm{Osw}\right)$, sea surface salinity and $\mathrm{Ba} / \mathrm{Ca}$ in $\mathrm{G}$. sacculifer in the Andaman Sea. This study suggests that the South Asian Summer Monsoon (SAM) over the Irrawaddy strengthened gradually after the LGM begins at $\sim 18$ ka. Early to mid-Holocene SAM variability is characterized by a gradual intensification of monsoon rainfall with constant upper-ocean stratification. Peak monsoon strength during the mid-Holocene in the Andaman Sea is likely to be linked with combined precession and obliquity forcing. Sijinkumar et al. (2016a) reported rapid refreshing of the Andaman Sea during the LGM and sea-level low stand resulting in reduced surface water mixing with the open Bay of Bengal (BoB). $\delta^{18} \mathrm{O}$ data of both surface and thermocline-dwelling species in the Andaman and northern BoB indicate colder and/or more saline conditions within the Younger Dryas. Sijinkumar et al. (2016b) adopted an abundance variation of $N$. dutertrei, G. rubescens, and benthic foraminifera to 
demonstrate abrupt changes in the climate and oceanography related to Dansgaard-Oeschger (D/O) events and HS of the North Atlantic documented in the Andaman Sea. The lower abundance of $N$. dutertrei (corresponds to G. rubescens maxima) during HS, deglacial, YD and mid- to late-Holocene suggests reduced freshwater influx from the Irrawaddy and precipitation as a result of the weakening of summer monsoon driven by the teleconnection between North Atlantic climate and Indian monsoon. Another study from Neil Island, Andaman, and the Nicobar Islands by Chakraborty and Ghosh, (2016) document a strong monsoonal system with relatively weaker intermittent monsoonal activity. The dominance of diatom Thalassionema nitzschioides confirms the strong monsoonal activity and upwelling during the late Miocene in the study area.

Panmei et al. (2017) investigated the response of tropical Indian Ocean sea surface temperature (SST) to events such as the younger dryas (YD). SST reconstruction from the western BoB exhibits overall warming of $1.88^{\circ} \mathrm{C}$ during the YD. No significant negative SST anomalies in both the Arabian Sea and the BoB compared to pre- and post-YD suggests that no apparent cooling occurred during the YD in the Northern Indian Ocean. In contrast, most part of the YD exhibits positive SST anomalies in the Northern Indian Ocean that coincide with the slowdown of the Atlantic Meridional Overturning Circulation during this period. Kiran Kumar et al. (2017) demonstrate that there is no evidence to believe that the south Asian summer monsoon steadily declined during the Holocene, as reported in the earlier papers from the Western Arabian Sea. Kiran Kumar et al. (2018) inferred summer monsoon was weaker during MIS-3 than the early Holocene but was stronger than during MIS-2 from the $\delta^{18} \mathrm{O}$ records of planktonic foraminifera. The $\delta^{18} \mathrm{O}$ of G. ruber in the Andaman Sea is more depleted than that from southern $\mathrm{BoB}$ but more enriched in $\delta^{18} \mathrm{O}$ in comparison with northern and western BoB core records during early Holocene. Sarathchandraprasad \& Banakar (2018) studied the last 42 kyr sediment chemistry of oxygendeficient coastal region (upper slope off Chennai) of the BoB. The $\delta^{18} \mathrm{O}$ G. sacculifer time-series exhibits distinct enrichment ( $\sim 4 \%$ ) during the last glacial period (30-18 ka), and depletion ( $-2.2 \%$ ) during the Holocene, suggesting a significant shift in ISM intensity.

Soukhire et al. (2018) assessed the applicability of temporal changes in living benthic foraminiferal morpho-groups (Fig. 7) from the shelf and slope of the central-western BoB to reconstruct past monsoon changes in the last 2000 years. These authors reported an increased monsoon discharge during the Medieval Warm Period (MWP) and lowered during the Little Ice Age (LIA) and described a close relationship between the Monsoon and the solar activity. Shrivastav et al. (2016) discussed the problem arising from the use of several variants of Globigerina bulloides by different authors, particularly in the light of extensive use of a relative abundance of $G$. bulloides and stable isotopic analyses of its test as proxy indicator of paleomonsoon. This study illustrates that the picking up of a single morphotype of G. bulloides for isotopic analyses and advocates for a detailed genetic study of various morphotypes to get an enlightened picture of the species concept. Manasa et al. (2016) discuss the ecological preferences of two benthic foraminiferal morpho-groups namely rounded symmetrical and angular asymmetrical benthic foraminifera to reconstruct paleomonsoon from continental shelf region of the northwestern BoB. Saraswat et al. (2017) studied the abundance and Ecology of Endemic Asterorotalia trispinosa from the Western BoB. The spatial variation of Asterorotalia trispinosa abundance suggested for paleomonsoon reconstructions based on their ecological preferences.

Naidu and Govil (2017) used $\delta^{18} \mathrm{O}$ and $\mathrm{Mg} / \mathrm{Ca}$ ratio of planktonic foraminifera $\mathrm{G}$. ruber from the $\mathrm{BoB}$. The study suggests that the monsoon could kick the start of millennial-scale abrupt climate changes through the shifts of the Intertropical Convergence Zone (ITCZ) and associated convection, water vapour supply to the tropical troposphere and latent heat penetration. Raza et al. (2017) published an $\delta^{18} \mathrm{O}$ and $\mathrm{Mg} / \mathrm{Ca}$ ratio based SST record of northern Indian Ocean using two sediment cores from NE Arabian Sea and southern BoB. The study suggests significant changes in SST and $\delta^{18} \mathrm{O}_{\text {sw }}$ since last glacial period. The glacial SSTs in the BOB and the NE Arabian Sea were lower by $\sim 2-2.5^{\circ} \mathrm{C}$ relative to the Holocene. The SST time series in both these regions indicates a sudden and abrupt increase in temperature at the end of LGM. The SST time series in the NEAS core SK 148-21 reveals an intensification of the northeast 
monsoon during the LGM. Study on both living (roseBengal stained) as well as dead agglutinated benthic foraminifera by Saalim et al., (2019) assess the ecological preferences in the western BoB. Morphogroups from the fresh-water influx dominates western $\mathrm{BoB}$ and exceptionally high agglutinated benthic foraminiferal are abundant on the slope of the western BoB. A comprehensive study by Uddandam et al., (2017) showed the spatial distribution of organic-walled dinoflagellates cyst in surface sediment samples from self and upper to middle slope in western BoB. Distribution of protoperidinioides in the upper-middle slope region in $\mathrm{BoB}$ indicted high nutrients and reducing environmental conditions for growth and preservation. Further, a new organic-walled dinoflagellate cyst Cristadinium striatiserratum sp. nov. has been reported from the modern sediments of the northern Indian Ocean (Uddandam et al., 2018) (Fig. 9).

Few studies carried In the Vestfold Hill region of Antarctica, Raaza et al. (2018) reported two past storm-cyclone events based on two sets of inverted sediments sections from the core. The past stormcyclone events based on the increased abundance of marine microfossils (foraminifera and diatoms in inverted layers) are suggestive of sediments transportation from the adjacent shelf. Saraswat et al. (2018) documented the spatial distribution of benthic foraminiferal morpho-groups from the Kongsfjorden-Krossfjorden and assessed its environmental significance. The significant correlation between foraminiferal parameters and water depth suggests that meltwater and glacial calving, as well as associated changes in the sedimentation rate, grain size, $\mathrm{pH}$ and organic carbon, affect benthic foraminifera in high latitudinal fjords.

The Southern Ocean is the least understood of the world's oceans, despite its vital role in the present climate system. Recent advances in the field of Southern Ocean paleoceanography by the Indian researchers have taken us a step closer to understanding the past climate variability at millennial and glacial-interglacial timescale. Nair and Mohan. (2017) reviewed in detail the paleoclimatic signals from the proxy records of the Southern Ocean to understand the past latitudinal variability of the Southern Ocean frontal systems and Antarctic sea-ice extent based on a multi-proxy approach. The multi-proxy approach includes diatom size and productivity, magnetic, geochemical, and sedimentological parameters. The high-resolution records of diatom frustules from the Southern Ocean sediment cores revealed the control of iron availability or by other environmental conditions such as SST and/or sea ice presence on the morphometric variation of different diatom species. Shukla et al. (2016) reported the first study on modern sediments from the Southern Ocean to explore the variability of the mean valve area of T. lentiginosa in relation to productivity and modern environmental conditions (Fig. 8). T. lentiginosa means valve area variations in four deep-sea cores across the frontal zones in the Atlantic and Indian sectors of the Southern Ocean resulted from changes in SST and sea-ice presence modulating the species ability to make use of nutrient stocks and controlling the length of its growing season, respectively. Shukla and Crosta (2017) suggested that more favourable SST, within the F. kerguelensis ecological range, during the Last Glacial period may have enabled $F$. kerguelensis to make better use of the low silica stocks prevailing in the subtropical zone leading to larger valves. Shukla and Romero (2018) studied the F. kerguelensis size variation in core GeoB3606-1 collected in the Benguela Upwelling System, where F. kerguelensis valves were preserved during the glacial period (68$30 / \mathrm{ka}$ ) as a consequence of silicic acid leakage from polar to mid-latitudes. The altered growth rates of $F$. kerguelensis cells are attributed to the availability of iron through increased dust flux during the interglacial and glacial periods (MIS3 and MIS4).

Nair et al. (2019) documented the interactions between Southern Hemisphere high-latitude (Antarctica \& Southern Ocean), southern Indian Ocean subtropics (Agulhas leakage) and Asian summer monsoon. Khare (2017) establish an interdependence of $\delta^{13} \mathrm{C}$ values of planktic species Globigerina bulloides and the overall size of planktic foraminiferal population linked with the generation of food/nutritive in the sector (between $9.69^{\circ} \mathrm{N}$ and $55.01^{\circ} \mathrm{S}$ latitude and $80^{\circ} \mathrm{E}$ and $40^{\circ} \mathrm{E}$ longitude). Patil et al. (2017) studied the cocolithophore diversity in the Southern Ocean and suggested a direct correlation of temperature and nutrient concentration in water and sea surface samples collected from in Indian Southern Ocean Expedition. Mishra et al. (2017) investigated the variability of chlorophyll- $a(C h l-a)$ and diatoms in the frontal ecosystems of the Indian 
sector of SO. The maximum concentration of $C h l-a$ and diatoms commonly observed in the SAF region are probably due to the moderate PAR, SST, and wind. The dominance of diatoms at the PF may be attributed to their adaptability for low light conditions. Hendrizan et al. (2016) studied the sediment core from the Andaman Sea which yielded 11 nannoplankton genus and discussed the importance of SEM images in nannofossil study. Taxonomy and detailed morphological description of calcareous nannoplankton from the Andaman Sea were explained in this study.

The systematic paleontology of textulariid, and miliolid foraminifera from the Arabian Sea has been carried out by Nimmy et al., (2018). Also, miliolid foraminifera from shallow waters off the rocky island of Andamans has reported by Rajeshwara Rao et al. (2018). A sediment core was studied to infer the paleoecological characteristics of Pichavaram mangrove ecosystem, foraminifera distribution, percentage of $\mathrm{CaCO}_{3}$ and organic matter content in the sediments (Jeyabal et al. 2016). Kannappan et al. (2016) studied community composition, density, richness, evenness, and diversity of meiobenthic fauna from Manakudy estuary, west coast of India. To investigate the rate of sedimentation and eutrophication processes in the Pulicat lagoon, Fulmali et al. (2017) studied a short core from the lake. The results suggest that bottom of core was dominated by the brackish water diatom species in hypertrophic conditions and top of the core was dominated by marine diatom species under the oligotrophic condition. The marine, as well as brackish water diatoms species, also show their tolerance towards pollutant which is caused by the anthropogenic activity. Studies on foraminifera distribution, ecology, sediment characteristics and its implication environmental changes in offshore region, river, and beach around Palk Strait, Tamil Nadu was studied (Suresh Gandhi et al., 2017; 2018, Kasilingam et al., 2019). Estuaries form Nellore coast, East India studied by Reddy et al. (2016) and reported foraminiferal test abnormalities in presence of heavy metal concentrations. Because of the effect of heavy metal pollution in these estuaries, drastic changes in the number of species and diversity of foraminifera were observed. Jeshma et al. (2017) studied the foraminiferal species to determine the environmental conditions in the Puravadaiyanar and Vettar estuary, Karaikal, along the southeast coast of
India. It has also reported that the impact of heavy metal pollution on benthic foraminifera was very less in the study area.

Gangadhara Rao \& Kumar (2016) have studied a rich assemblage of foraminifera for ecological interpretations from the east coast of India (Gosthani River Estuary, Andhra Pradesh). Rajeshwara Rao (2016) presented a thorough review of foraminifera studies from the Muthupet Lagoon and also studied three cores to elaborate infaunal characteristics of benthic foraminifera from Muthupet Lagoon. Bhaumik et al., (2017) discussed the habitat-wise isotopic variation and estimation of isotopic correction factors for the paired species benthic foraminifera from the Krishna-Godavari basin and Peru offshores. Tripathi et al., (2018a) report the basin submergence in part of Sundarban mangrove delta with evidence from benthonic foraminiferal assemblages. The peculiar presence of intertidal assemblage above the upper marshes assemblages in recent sediment points towards the theory of submergence due to relative rise in the sea level. To understand the submarine behavior of these channels and associated meiobenthos, benthic foraminifera were studied from off Bakkhali, West Bengal, India (Tripathi et al., 2018 b). The study reveals that a total of fifteen species of recent present and their distribution mainly controlled by channel morphology and sediment character. In a case study from the Zuari estuary, Goa (Saalim et al., 2017) reported the response of benthic foraminifera to changes in mining pattern and discussed the use of benthic foraminifera as an effective tool to monitor the impact of mining. They further suggest that the potential counter effect of terrigenous dilution on total and living benthic foraminiferal population should be considered while interpreting temporal variations in foraminiferal abundance in marginal marine settings. Dubey et al., (2018) studied seasonal foraminiferal distribution in the Mudbank formation to understand the foraminiferal response to Physico-chemical changes associated with mudbank formation off Alleppey, Kerala and found low diversity of benthic foraminifera in the mudbank during both pre-monsoon and monsoon season which suggests a stressed environment.

A comprehensive review of the occurrence and implications of Ostracodes is presented by Hussain (2017) from the east and west coast of India. A fair 
assemblage of foraminifera and ostracods were recorded by Hussain and Casey (2016) from the North Chennai Coast, Tamil Nadu. Identified species of foraminifera and ostracods are characteristics of the benthic, shallow, inner shelf (inner neritic) to marginal marine, tropical and distributed in intertidal sediments due to tides as well as longshore currents. They have also reported one endemic ostracoda species namely Basslerites liebaui. Again fair population of foraminifera and ostracoda were recorded by Hussain et al. (2016) from the Kovalam beach, Thiruvananthapuram, Kerala. The distribution pattern of the individual taxon was examined, and their sediment relationship was determined for environmental interpretation. Hussain et al. (2017) studied foraminifera and ostracoda for ecological implications from the beach sands of Tuticorin Coast, Tamil Nadu and found that sand substrate was congenial for the population abundance. Predation marks on foraminiferal tests and change in their color have also noticed in few species with few broken and abraded tests which indicates the high amplitude of tidal agitation and comparatively low deposition of sand in the beach environment of Tuticorin coast. Hussain et al. (2018) studied the systematic and distribution of recent brackish water Ostracoda from the Pulicat lagoon, Tamil Nadu. An attempt has also been made to bring out the relation between the sediment characteristics and the Ostracoda population and to evaluate the favourable substrate for the population abundance in Pulicat Lagoon. From the study, it was inferred that the sandy substrate is congenial sediment type for the population abundance and distribution of ostracoda. Nazeer et al. (2018) carried out a preliminary study on marine ostracoda from BoB core. Depth-related distribution of ostracod fauna was reported from the seven transects of Sagar Kanya, SK 308 Leg-1, off central BoB (Nishath et al. 2017). The study displayed the maximum diversity of ostracods in shallower water rather than in the deeper water, which may be due to the optimum temperature, $\mathrm{pH}$ salinity, and substrate. It also provides a detailed account of bathymetry and associated changes in ostracod biodiversity.

Nigam et al. 2016 published a study from Dholavira, Gujarat India, suggesting that the ancient Indians (Harappan settlements) were aware of Tsunami/storm protection measures. They built fortification of maximum wall thickness up to $18 \mathrm{~m}$, which is extraordinary. Sreenivasulu et al. (2017a) presented a review of field and laboratory methods that have been used in recent foraminiferal studies (between 2000 and 2015) in the Indian coastal regions. Also, they attempted to quantify the organic matter using Fourier Transform Infrared Spectroscopy (FTIR) in benthic foraminifera shell from the Tupilipalem coast, BoB, Southeast coast of India (Sreenivasulu et al. 2017b). Their study suggests both a shift to a higher frequency and an increase in absorption strength for the band were observed from the beach and brackish environments. It indicates that the biological activity for brackish water is modified significantly due to its higher nutrient concentration. Sreenivasulu et al. (2019) used benthic foraminifera as a bio-indicator for assessing the environmental stress in the Beypore estuary. They computed the benthic foraminiferal diversity index and inferred that the estuary was dominated by stress-tolerant taxa due to the prevalence of hypoxic (low-oxygen) conditions.

Kurtarkar et al. (2017) reviewed the recent experimental research on foraminifera regarding factors that bring about changes in benthic foraminiferal abundance, diversity, morphology, the isotopic and chemical composition of the test. Also, they conducted a laboratory culture experiment on Cymbaloporetta plana to understand the coupled effect of temperature and food (Kurtarkar et al., 2019). From the experiments, they reported that at all temperatures, growth increased with an increase in food. They suggest warming, coupled with decreasing productivity is likely to affect the growth and abundance of shallow-water benthic foraminifera severely.

A textbook on "Micropaleontology and Its Applications" authored by the Kathal P K, Nigam R and Talib A (2017). This book is useful for the young researchers and students to understand the processes of micropaleontology and broader application.

\section{Summary}

The utility of foraminifera, nannoplankton, dinoflagellate, ostracod, diatoms, coralline algae, and radiolarian, etc. in the sediments has been well established in the recent decades for the paleoceanographic and paleoclimatologic studies. In this article, the authors describe the applicability of different microfossil proxies in ocean/marginal marine 
regimes to understand the paleoclimatic, paleoceanographic and environmental changes. We identify and highlight the significant on-going discussions and gaps in knowledge which we expect to define the next decade of multiple disciplinary research into past palaeoenvironmental, paleoceanographic and paleoclimatic reconstruction. Few contributions span from extant to extinct (Permian-Pliocene) microfossil research with an emphasis on ecology, biofacies, and paleoecology in the Indian subcontinent as well as those working throughout the Indian Ocean region and beyond (Kathal et al., 2017). One report published on the deeper time scale (Paleozoic era: late Ordovicianearly Silurian) record of calcareous green algae from Tethyan Himalaya of India (Shabbar et al. 2019). Recent studies from the Callovian age sediments of Fakirwari and Habo domes (Kutch Basin) were deposited in open marine middle and middle to outer shelf respectively with the fluctuating shoreline. The foraminiferal assemblages of these two domes show connectivity with Indo-East African Province while the Kimmeridgian age dinoflagellate cyst recorded from Wagad Uplift situated towards the east of Kutch Basin show Gondwanan (Australasian) affinity. More studies on this aspect are required (based on different marine microfossils) to give a better picture of the paleogeographical position of the Indian subcontinent in Jurassic time. The succession deposited during the K-Pg transition from Central India has provided a remarkable study related to the timing of angiosperm diversification. In another study from NE India, a pulse of warming superimposed on global cooling has been recorded just before the K-Pg transition.

From the Paleogene period of India, work

\section{References}

Agrawal S, Verma P, Rao M R, Garg R, Kapur V V and Bajpai S (2017) Lignite deposits of the Kutch Basin, western India: Carbon isotopic and palynological signatures of the early Eocene hyperthermal event ETM2 Journal of Asian Earth Sciences 146 296-303

Azharuddin S, Govil P, Singh A D, Mishra R and Shekhar M (2019) Solar insolation driven periodicities in southwest monsoon and its impact on NE Arabian Sea paleoceanography Geoscience Frontiers https://doi.org/ 10.1016/j.gsf.2019.03.007 has been done from NE and western India using several biotic proxies for a systematic, biostratigraphic and paleobiogeographical framework. In recent years the abiotic proxies such as geochemical characterization including stable isotope studies, facilitated better identification of signals of paleoenvironmental variability even up to demarcation of the global climate events of Paleogene times. Neogene marine microfossil studies enhanced understanding of their biostratigraphic ranges and facies relationships as a tool for the study of shallow-water carbonate deposits.

Quantification of the past climate change is necessary for the reconstruction of reliable models to understand the present and/or future predictions. Excellent studies have been carried out in the Quaternary period by Indian scientists to understand the paleoclimatic, paleoenvironmental and paleoceanographic changes in the Indian Ocean (including the Arabian Sea and Bay of Bengal), Southern Ocean, coastal and estuarine regions (SW and SE coast, India). These high-resolution studies provided both short-term and long-term changes in the Indian monsoon system, land-sea interaction, oceanic teleconnections, etc. Still, few gaps exist in our knowledge of the robustness of different proxies used in providing quantitative and qualitative insight into past and present climatic conditions. It is crucial to understand that these proxy parameters can be universal and the proper use of these records is necessary for a comprehensive perspective on past environments. The increasing participation in the ongoing global scientific programs and active involvement can fill the gap and augurs well for the future progress of geoscience studies in India.

Azharuddin S, Govil P, Singh A D, Mishra R, Agrawal S, Tiwari A K and Kumar K (2017) Monsoon-influenced variations in productivity and lithogenic flux along offshore Saurashtra, NE Arabian Sea during the Holocene and Younger Dryas: A multi-proxy approach Palaeogeography Palaeoclimatology Palaeoecology 483 136-146

Banerjee B, Ahmad S M, Raza W and Raza T (2017) Paleoceanographic changes in the Northeast Indian Ocean during middle Miocene inferred from carbon and oxygen isotopes of foraminiferal fossil shells Palaeogeography Palaeoclimatology Palaeoecology 466 166-173 
Banerjee S, Khanolkar S and Saraswati P K (2018) Facies and depositional settings of the Middle Eocene-Oligocene carbonates in Kutch Geodinamica Acta 30 119-136

Bhat B A, Talib A and Wasim S M (2016) Systematics, age, paleoecology and paleobiogeography of Jurassic foraminifera from Fakirwari Dome, Kutch, Gujarat, India Micropaleontology 62 171-194

Bhaumik A K, Kumar S, Ray S, Vishwakarma G K, Gupta A K, Kumar P and Sain K (2017) Stable carbon and oxygen isotope study on benthic foraminifera: Implication for microhabitat preferences and interspecies correlation Journal of Earth and System Sciences 12672

Chakraborty A and Ghosh A K (2016) Ocean upwelling and intense monsoonal activity based on late Miocene diatom assemblages from Neil Island, Andaman and Nicobar Islands, India Marine Micropaleontology 127 26-41

Chakraborty A, Ghosh A K, Dey R, Saxena S and Mazumder A (2018) Record of the Miocene Climate Optimum in the northeast Indian Ocean: evidence from the microfossils Palaeobiodiversity and Palaeoenvironments Doi: org/ 101007/s12549-018-0342-3

Das M, Singh R K, Gupta A K and Bhaumik A K (2017) Holocene strengthening of the Oxygen Minimum Zone in the northwestern Arabian Sea linked to changes in intermediate water circulation or Indian monsoon intensity Palaeogeography Palaeoclimatology Palaeoecology 483 125-135

Dubey R, Saraswat R and Nigam R (2018) Mudbank offAlleppey, India: A bane for foraminifera but not so for carbon burial Science of the Total Environment 634 459-470

Fulmali S T, Hussain S M, Sunitha D and Humane S K (2017) Diatoms Distribution and its Paleoenvironmental Implications in Pulicat Lagoon, Tamil Nadu, south east coast of India International Journal of Science and Research 6 Doi: 1013140/RG222768437766

Gangadhara Rao K and Anil Kumar R (2016) Recent Foraminifera from the Gosthani River Estuary back water along the East Coast of India Andhra Pradesh International Journal of Scientific \& Engineering Research 7 515-517

Gebregiorgis D, Hathorne E C, Sijinkumar A V, Nagender Nath B, Nürnberg D and Frank M (2016) South Asian summer monsoon variability during the last <"54 kyrs inferred from surface water salinity and river runoff proxies Quaternary Science Reviews 138 6-15

Gogoi B, Prasad V, Garg R and Singh I B (2018) Palynofacies study of Lakadong Limestone (Late Paleocene) of Mawsynram area, Shillong Plateau, India: Implications for sequence stratigraphy In: The Indian Paleogene (Eds:
Bajpai S, Tripathi S C and Prasad V) Springer 187-207

Hendrizan M, Troa R A, Zuraida R and Triarso E (2016) Calcareous Nannoplankton (marine algae) Analysis in Subsurface Sediments of Andaman Sea Bulletin of the Marine Geology 31 91-98

Humane S K, Humane S S, Chaurpagar S N and Kundal P (2017) Halimedacean and Udoteacean calcareous algae from the Early Eocene subsurface carbonates platform of the Bengal Basin, India: paleoenvironmental aspects Micropaleontology 62 311-322

Hussain S M (2017) An Overview of Ostracoda studies from the freshwater, marginal marine and marine ecosystems of Andaman and Nicobar islands and the coasts of India In: Micropaleontology Commemorative Volume of Prof S N Bhalla (Eds: Kathal P K, Nigam R and Talib A) Scientific Publishers (India) 135-162

Hussain S M and Casey K E (2016) Distribution of Foraminifera and Ostracoda in the North Chennai Coast (Ennore to Thiruvanmiur), Tamil Nadu: Implications on Microenvironment Indian Journal of Geo-Marine Sciences 45 416-424

Hussain S M, Joy M M, Rajkumar A, Nishath N M and Fulmali S T (2016) Distribution of calcareous microfauna (Foraminifera and Ostracoda) from the beach sands of Kovalam, Thiruvananthapuram, Kerala, southwest coast of India Journal of the Palaeontological Society of India $6 \mathbf{1}$ 267-272

Hussain S M, Rajkumar A, Nishath N M, Sakthivel M and Selvasundaram S (2017) Distribution of Foraminifera and Ostracoda and their Ecological Conditions in the Beach Sands of Tuticorin, Tamil Nadu, Southeast Coast of India International Journal of Earth Sciences and Engineering 10 281-288

Hussain S M, Mahalakshmi P and Selvasundaram S (2018) Distribution of Ostracods in the mangrove location of Pulicat Lagoon, Tamil Nadu, south east coast of India Asian Academic Research Journal of Multidisciplinary 5 234250

Jeshma P, Suresh Gandhi M and Rajeshwara Rao N (2017) Benthic foraminifera and geochemical assessment of Puravadaiyanar and Vettar estuaries, Karaikal, south east coast of India - Implication for pollution monitoring studies Regional Studies in Marine Science 9 76-88

Jeyabal G, Muralidharan S, Ramasamy S, Rajeshwara Rao N, Krishna Kumar S and, Parthasarathy P (2016) Vertical distribution of foraminifera species and palaeo-ecology of the Pichavaram mangrove ecosystem, Southeast coast of India Journal of Coastal Sciences 3 1-7 
Kalia P and Sahu L R (2018) Middle Eocene-Lower Oligocene climatic transition and planktonic foraminiferal biostratigraphy at DSDP Sites 219 and 237, Arabian Sea and Western tropical Indian Ocean In: The Indian Paleogene (Eds: Bajpai S, Tripathi S C and Prasad V) Springer 263291

Kannappan T, Karthikeyan M M and Amutha C (2016) Meiobenthic faunal composition of Manakudy Estuary, southwest coast of India International Journal of Pure and Applied Zoology 4 1-7

Kasilingam K, Suresh Gandhi M and Rajeshwara Rao N (2019) Textural characteristics and ecology of near shore benthic foraminifera from Kottaipattinam to Kodiyakarai, Palk Strait, Southeast Coast of India Regional Studies in Marine Science 29100632 https://doi.org/10.1016/j.rsma. 2019.100632

Kathal P K, Nigam R and Talib A (2017) Micropaleontology and Its Applications: A Festschrift for Septuagenarian Scholar Professor Satyendra Nath Bhalla Scientific Publishers, India $349 \mathrm{pp}$

Khanolkar S and Saraswati P K (2016) Some observations on an atypical planktic foraminifer from the Middle Eocene of Kutch, India Journal of Micropaleontology 35 54-61

Khanolkar S and Saraswati P K (2019) Eocene foraminiferal biofacies in Kutch Basin (India) in context of palaeoclimate and palaeoecology Journal of Palaeogeography 821 https:/ /doiorg/101186/s42501-019-0038-2

Khanolkar S and Sharma J (2019) Record of Early to Middle Eocene paleoenvironmental changes from lignite mines, western India Journal of Micropalaeontology 38 1-24

Khanolkar S, Saraswati P K and Rogers K (2017) Ecology of foraminifera during the middle Eocene climatic optimum in Kutch, India Geodinamica Acta 29 1-13

Khare N (2017) Dependence of the stable carbon isotope of planktic foraminiferal species Globigerina Bulloides on food supply in the Indian Ocean sector of Southern Ocean Geosciences Research 2 236-241

Khare N, Nigam R, Mayenkar D N and Saraswat R (2017) Cluster analysis of benthic foraminiferal morpho-groups from the western margin of India reflects its depth preference Continental Shelf Research 151 72-83

Kiran Kumar P and Ramesh R (2017) Revisiting reconstructed Indian monsoon rainfall variations during the last $<$ " $25 \mathrm{ka}$ from planktonic foraminiferal $\ddot{a}^{18} \mathrm{O}$ from the Eastern Arabian Sea Quaternary international 443 29-38

Kiran Kumar P, Band S T, Ramesh R and Awasthi N (2018) Monsoon variability and upper ocean stratification during the last <"66 ka over the Andaman Sea: Inferences from the $\ddot{a}^{18} \mathrm{O}$ records of planktonic foraminifera Quaternary International 479 12-18

Koley T, Lahiri A, Wanjarwadkar K M and Anju C S (2018) Palaeocene faunal events and fossil records of Andaman Islands, India In: The Indian Paleogene (Eds: Bajpai S, Tripathi S C and Prasad V) Springer 249-262

Kurtarkar S R, Linshy V N, Kaithwar A, Saraswat R and Nigam R (2017) Experimental studies on benthic foraminifera: An update on the changing trends and challenges over the past decade. In: Micropaleontology and its applications (Eds: Kathal PK, Nigam R and Talib A) Scientific Publishers (India) $311-330$

Kurtarkar R S, Saraswat R, Kaithwar A and Nigam R (2019) How will Benthic Foraminifera Respond to Warming and Changes in Productivity?: A Laboratory Culture Study on Cymbaloporetta plana Acta Geologica Sinica 93 175182

Less G, Frijia G, Özcan E, Saraswati P K, Parente M and Kumar P (2018) Nummulitids, lepidocyclinids and Sr-isotope data from the Oligocene of Kutch (western India) with chronostratigraphic and paleobiogeographic evaluations Geodinamica Acta 30 183-211

Malarkodi N, Özcan E, Venkataraman D, Somappa S C, Gowda S, Nagaraja P K T and Yücel A O (2017) Lepidorbitoides (Foraminifera) from the lower Maastrichtian Kallankuruchchi Formation, Cauvery Basin, India: Morphometry and paleobiogeography Cretaceous Research 77 143-157

Manasa M, Saraswat R K and Nigam R (2016) Assessing the suitability of benthic foraminiferal morpho-groups to reconstruct paleomonsoon from Bay of Bengal Journal of Earth System Science 125 571-584

Mishra R K, Jena B, Narayana Pillai A, Naik R K, Parli V B and Soares M (2017) Variability of chlorophyll-a and diatoms in the frontal ecosystem of Indian Ocean sector of the Southern Ocean Polish Polar Research 38 375-392

Mukhopadhyay S K (2016) Planktonic foraminiferal zonation and sea-level changes in the upper Maastrichtian-middle Danian successions of Meghalaya, India Stratigraphy 13 245-276

Mukhopadhyay S K (2018) Implication of the occurrence of minute biotic bodies on the conjoined Nummulites aff. Nummulites acutus (Sowerby) in the subsurface Eocene of Cauvery Basin, India In: The Indian Paleogene (Eds: Bajpai S, Tripathi S C and Prasad V) Springer 225-247

Naidu P D and Govil P (2019) Monsoon Could Trigger the Global Abrupt Climate Changes: New Evidence from the Bay of Bengal Journal of Indian Geophysical Union 21 285-291 
Naidu P D, Niitsuma N, Thirumalai K and Naik S S (2019) Significant seasonal contrast in the Arabian Sea during deglaciation: Evidence from oxygen isotopic analyses of individual planktic foraminifera Quaternary International 503 163-169

Naik S S (2016) A comparison of Mg-Ca ratios in Globigerinoides ruber (white)- sensu stricto versus a mixture of genotypes Journal of the Geological Society of India $\mathbf{8 7} 323$

Naik S N and Naik S S (2018) Evidences of $\mathrm{CO}_{2}$ Leakage During the Last Deglaciation- The Need to Understand Deepocean Carbonate Chemistry of the Arabian Sea Journal of the Geological Society of India 92404

Naik D K, Saraswat R, Lea D W, Kurtarkar S R and Mackensen A (2017) Last glacial-interglacial productivity and associated changes in the eastern Arabian Sea Palaeogeography Palaeoclimatology Palaeoecology 483 $147-156$

Nair A and Mohan R (2017) Paleoclimatic Signals from the Proxy Records of the Southern Ocean- A Review Proceedings of the Indian National Science Academy 83 279-287

Nair A, Mohan R, Crosta X, Manoj M C, Marieu V and Thamban M (2019) Southern Ocean sea ice and frontal changes during the late Quaternary and their linkages to Indo-Asian summer monsoon Quaternary Science Reviews 213 93104

Nazeer M N, Hussain S M, Nishath N M, Krishna V M and Sunitha D (2018) Granulometric studies, rate of sedimentation and Ostracod distribution from a short core off Ongole coast, Andhra Pradesh, Bay of Bengal Journal of the Palaeontological Society of India 63 111-118

Nigam R, Dubey R, Saraswat R, Gaur A S and Loveson V J (2016) Ancient Indians (Harappan Settlement) were Aware of Tsunami/Storm Protection Measures: A New Interpretation of Thick Walls at Dholavira, Gujarat, India Current Science 111 2040-2043

Nimmy P M, Rajeshwara Rao N, Nandita Nandan T, Neelavannan K and Hussain S M (2018) Textulariid and Miliolid Foraminifera from a $50 \mathrm{~cm}$ core segment from the Arabian Sea International Journal of Creative Research Thoughts 6 957-973

Nishath N M, Hussain S M, Neelavnnan K, Thejasino S, Saalim $\mathrm{S}$ and Rajkumar A (2017) Ostracod biodiversity from shelf to slope oceanic conditions, off central Bay of Bengal, India Palaeogeography Palaeoclimatology Palaeoecology DOI: org/101016/jpalaeo201705004

Özcan E, Saraswati P K, Hanif M and Ali N (2016) Orthophragminids with new axial thickening structures from the Bartonian of the Indian subcontinent Geologica
Acta 14 261-282

Özcan E, Pignatti J, Pereira C, Yücel A O, Drobne K, Barattolo F and Saraswati P K (2018) Paleocene orthophragminids from the Lakadong Limestone, Mawmluh Quarry section, Meghalaya (Shillong, NE India): implications for the regional geology and paleobiogeography Journal of Micropalaeontology 37 357-381

Pal S, Shrivastava J P and Mukhopadhyay S K (2018) Foraminiferal effects of regional fire and attendant paleoenvironment during $\mathrm{K} / \mathrm{Pg}$ transition: organo-chemical evidence from the Um Sohryngkew River section, Meghalaya, India In: The Indian Paleogene (Eds: Bajpai S, Tripathi S C and Prasad V) Springer 135-150

Panmei C, Naidu P D and Mohtadi M (2017) Bay of Bengal exhibits warming trend during the Younger Dryas: Implications of AMOC Geochemistry Geophysics Geosystems 18 4317-4325

Patil S M, Mohan R, Shetye S S, Gazi S, Baumann K-H and Jafar $S$ (2017) Biogeographic distribution of extant Coccolithophores in the Indian sector of the Southern Ocean Marine Micropaleontology 137 16-30

Prasad V, Farooqui A, Murthy S, Sarate O S and Bajpai S (2018) Palynological assemblage from the Deccan Volcanic Province, central India: Insights into early history of angiosperms and the terminal Cretaceous paleogeography of peninsular India Cretaceous Research 86 186-198

Prasad V, Utescher T, Sharma A, Singh I B, Garg R, Gogoi B, Srivastava J, Uddandam P R and Joachimski M M (2018) Low-latitude vegetation and climate dynamics at the Paleocene-Eocene transition - A study based on multiple proxies from the Jathang section in northeastern India Palaeogeography, Palaeoclimatology, Palaeoecology 497 139-156

Rai A, Pathak V K, Sharma L and Hussain A (2017) Pliocene Indonesian Through flow Change and Planktic Foraminiferal Diversity in the Eastern Subtropical Indian Ocean Current Science 113 955-959

Rai J (2018) Nannofossil Imprints of Paleogene Transgressive Events in India In: The Indian Paleogene (Eds: Bajpai S, Tripathi S C and Prasad V) Springer 209-223

Rajeshwara Rao N, Anbalagan S and Pasupathi R (2016) Infaunal Characteristics of Benthic Foraminifera from the Muthupet Lagoon Ecosystem, South-East Coast of India International Journal of Scientific Research in Science, Engineering and Technology 2 2394-4099

Rajeshwara Rao N, Nimmy P M, Velmurugan P M, Jayaprakash M and Manuprasad P K (2018) Miliolid (benthic) foraminifera from shallow waters off the Rocky Island, 
Andamans, India International Journal of Creative Research Thoughts 6 726-759

Raju D S N (2018) Paleogene stratigraphy of India: An overview In: The Indian Paleogene (Eds: Bajpai S, Tripathi S C and Prasad V) Springer 1-89

Raza M A, Saraswat R, Bhadra S R, Naik D K, Khare N, Govil P and Mazumder A (2018) Inverted sediments in the coastal Antarctic lake: Evidence of paleostorm Polar Science 18 213-219

Reddy B C S R, Jayaraju N, Sreenivasulu G, Suresh U and Reddy A N (2016) Heavy metal pollution monitoring with foraminifera in the estuaries of Nellore coast, East coast of India Marine Pollution Bulletin 113 542-551 https://doi.org/ 10.1016/j.marpolbul.2016.08.051

Riding J B, Garg R and Rai J (2017) Dinoflagellate cyst biostratigraphy of the Patasar Shale Member (Upper Jurassic) of the Wagad Uplift, Kachchh, Gujarat, western India Review of Palaeobotany and Palynology 243 37-46

Saalim S M, Saraswat R and Suokhrie T (2017) Benthic foraminiferal response to changes in mining pattern- a case study from the Zuari estuary, Goa, India Environmental Earth Sciences $\mathbf{7 6} 706$

Saalim S M, Saraswat R, Suokhrie T and Nigam R (2019) Assessing the ecological preferences of agglutinated benthic foraminiferal morphogroups from the western Bay of Bengal Deep Sea Research Part II: Topical Studies in Oceanography $16138-51$

Saraswat R, Roy C, Khare N, Saalim S M and Kurtarkar S R (2018) Assessing the environmental significance of benthic foraminiferal morpho-groups from the northern high latitudinal regions Polar Science 18 28-38

Saraswat R, Manasa M, Suokhrie T, Saalim S M and Nigam R (2017) Abundance and ecology of endemic Asterorotalia trispinosa from the western Bay of Bengal: implications for its application as paleomonsoon proxy Acta Geologica Sinica 91 2268-2282

Saraswat R, Naik D K, Nigam R and Gaur A S (2016) Timing, cause and consequences of mid-Holocene climate transition the Arabian Sea Quaternary Research 86 162-169

Saraswati P K, Banerjee S, Sarkar U, Chakraborty S and Khanolkar S (2016a) Eocene Depositional Sequence and Cycles in Kutch Special publication of the Geological Society of India 6 46-56

Saraswati P K, Khanolkar S, Raju D S N and Banerjee S (2016b) An Updated Eocene Stratigraphy of Kutch Special publication of the Geological Society of India 6 25-31

Saraswati P K, Anwar D and Lahiri A (2017) Bartonian reticulate
Nummulites of Kutch Geodinamica Acta 29 14-23

Saraswati P K, Khanolkar S and Banerjee S (2018) Paleogene stratigraphy of Kutch, India: an update about progress in foraminiferal biostratigraphy Geodinamica Acta 30 100118

Sarathchandraprasad T and Banakar V K (2018) Last 42 Ky sediment chemistry of oxygen deficient coastal region of the Bay of Bengal: Implications for terrigenous input and monsoon variability Current Science 114 1940-1946

Sarkar S (2016) Early Eocene Calcareous Algae and Benthic Foraminifera from Meghalaya, NE India: A New Record of Microfacies and Palaeoenvironment Journal of the Geological Society of India $\mathbf{8 8}$ 281-294

Sarkar S (2017a) Microfacies analysis of larger benthic foraminifera-dominated Middle Eocene carbonates: a palaeoenvironmental case study from Meghalaya, N-E India (Eastern Tethys) Arabian Journal of Geosciences doi: 10 101007/s12517-017-2929-9

Sarkar S (2017b) Ecology of coralline red algae: Fossil evidences from India Thalassas 33 doi: 101007/s41208-016-0017-7

Sarkar S (2018) The enigmatic Palaeocene-Eocene coralline Distichoplax : Approaching the structural complexities, ecological affinities and extinction hypotheses Marine Micropaleontology doi: 139 101016/jmarmicro201712001

Sarkar S (2019) Does specialization imply rare fossil records of some benthic foraminifera: Late Palaeocene examples from the eastern Neo-Tethys (Meghalaya, NE India) Palaeogeography, Palaeoclimatology, Palaeoecology 514 124-134

Sarkar S, Ghosh A K and Rao M N G (2016) Coralline algae and benthic foraminifera from the Long Formation (middle Miocene) of the Little Andaman Island, India: Biofaciesanalysis, systematics and palaeoenvironmental implications Journal of the Geological Society of India $\mathbf{8 7}$ 69-84

Sarkar S and Rao M N G (2018) Coralline red algae from late Palaeocene-earliest Eocene carbonates of Meghalaya, $\mathrm{N}-$ E India: palaeocommunity and trophic-level implications Carbonates and Evaporites DOI: 101007/s13146-018$0422-5$

Satpathy R, Steinke S and Singh A (2019) Monsoon-induced changes in surface hydrography of the eastern Arabian Sea during the early Pleistocene Geological Magazine 1-11 DOI: $10.1017 / \mathrm{S} 0016756819000098$

Shabbar H, Saxena A, Singh K J and Goswami S (2019) Cyclocrinitids from the Lower Palaeozoic Tethyan sequence of Spiti, India Palaeoworld https://doi.org/ 10.1016/j.palwor.2019.07.007 
Shrivastav A, Singh A K, Sinha D K, Kaushik T, Singh V P and Mallick K (2016) Significance of Globigerina bulloides d'orbigny: a foraminiferal proxy for palaeomonsoon and past upwelling records Journal of climate change 2 99110 DOI: $10.3233 /$ JCC-160021

Shukla S K and Romero O E (2018) Glacial valve size variation of the Southern Ocean diatom Fragilariopsis kerguelensis preserved in the Benguela Upwelling System, southeastern Atlantic. Palaeogeography Palaeoclimatology Palaeoecology 499 112-122

Shukla S K, and Crosta X (2017) Fragilariopsis kerguelensis size variability from the Indian subtropical Southern Ocean over the last 42000 years Antarctic Science 29 139-146 http://doi:10.1017/S095410201600050X

Shukla S K, Crespin J and Crosta X (2016) Thalassiosira lentiginosa size variation and associated biogenic silica burial in the Southern Ocean over the last 42kyrs Marine Micropaleontology 127 74-85

Sijinkumar A V, Nagender Nath B and Clemens S (2016a) North Atlantic climatic changes reflected in the Late Quaternary foraminiferal abundance record of the Andaman Sea, northeastern Indian Ocean Palaeogeography Palaeoclimatology Palaeoecology 446 11-18

Sijinkumar A, Clemens S, Nath B N, Prell W, Benshila R and Lengaigne $\mathrm{M}(2016 \mathrm{~b}) \mathrm{d}^{18} \mathrm{O}$ and salinity variability from the Last Glacial Maximum to recent in the Bay of Bengal and Andaman Sea Quaternary Science Review 135 79-91

Singh A (2018) Latest Maastrichtian palaeoclimatic and depositional environmental perturbations, a record from Micula prinsii Zone of Meghalaya, northeastern India The Palaeobotanist 67 209-219

Singh A and Rai J (2017) Cretaceous calcareous nannofossils from Tanot \#1, Jaisalmer Basin, Rajasthan, Western India: morphotaxonomy and Biostratigraphy The Palaeobotanist 66 85-176

Singh S D and Raju D S N (2018) Morphometric Data on Miogypsina (Lepidosemicyclina) bifida, Foraminifera from L-III Reservoir, Mumbai Offshore, India Journal of the Geological Society of India 91 329-333

Singh A K, Tiwari M, Srivastava A, Sinha D K and Ramesh R (2016) Wind Strength Variability in the Western Arabian Sea since the Last Glacial Maximum: Southwest vs Northeast Monsoon Modes Journal of Climate Change 2 $57-70$

Singh A, Rai J and Garg R (2016) Record of Late Eocene (Priabonian) nannofossils from the lower part of the Rewak Formation, Garo Hills, Meghalaya, northeastern India Journal of the Palaeontological Society of India 61 91-97
Singh D P, Saraswat R, Naik D K and Nigam R (2017) A first look at factors affecting aragonite compensation depth in the eastern Arabian Sea. Palaeogeography, Palaeoclimatology, Palaeoecology 483 6-14

Singh D P, Saraswat R and Kaithwar A (2018) Changes in standing stock and vertical distribution of benthic foraminifera along a depth gradient (58-2750 m) in the southeastern Arabian Sea Marine Biodiversity 48 73. https://doi.org/10.1007/ s12526-017-0823-z

Singh Y R, Sijagurumayum U and Singh B P (2018) Molluscan biostratigraphy and palynological assemblage of Paleogene Disang Formation, Manipur, India In: The Indian Paleogene (Eds: Bajpai S, Tripathi S C and Prasad V) Springer 309327

Sinha P and Halder K (2018) The Oligocene corals had circumtropical distribution In: The Indian Paleogene (Eds: Bajpai S, Tripathi S C and Prasad V) Springer 293-308

Sreenivasulu G, Jayaraju N, Sundara Raja Reddy B C, Lakshmi Prasad T, Nagalakshmi K and Lakshmanna B (2017) Foraminiferal research in coastal ecosystems of India during the past decade: A review Geo Res $J 13$ 38-48

Sreenivasulu G, Jayaraju N, Sundara Raja Reddy B C, Lakshmi Prasad T, Nagalakshmi K and Lakshmann B (2017) Organic matter from benthic foraminifera (Ammonia beccarii) shells by FT-IR spectroscopy: A study on Tupilipalem, South east coast of India Methods X 55-62

Sreenivasulu G, Praseetha B S, Daud N R, Varghese T I, Prakash $\mathrm{T} \mathrm{N}$ and Jayaraju N (2019) Benthic foraminifera as potential ecological proxies for environmental monitoring in coastal regions: A study on the Beypore estuary, Southwest coast of India Marine Pollution Bulletin 138 341-351

Suokhrie T, Saalim S M, Saraswat R and Nigam R (2018) Indian monsoon variability in the last 2000 years as inferred from benthic foraminifera Quaternary International 479 128140

Suresh Gandhi M, Kasilingam K, Arumugam T, Lalthansangi and Rajeswara Rao N (2017) Distribution of benthic foraminifera, sediment characteristics and its environmental conditions in and around Manalmelkudi Spit, Palk Strait, Tamil Nadu, East coast of India Indian Journal of GeoMarine Sciences 46 519-533

Suresh Gandhi M, Rajeswara Rao N, Kasilingam K and Raja M (2018) Distribution, ecology and paleoenvironments of Benthic foraminifera - A case study off Manora, Palk Strait, Tamil Nadu Indian Journal of Geo Marine Sciences 47 281-290

Talib A, Wasim S M, Sabeeha and Arkan M (2017) Jurassic 
Foraminifera from the Dharang Member, Habo Formation, Habo Dome, Kutch, India: systematics, age, palaeoecology and palaeobiogeography Journal of Systematic Palaeontology 15 403-426

Tripathi S K, Dengupta D, Sathikumar R, Baraik S and Lahiri A (2018a) Foraminiferal evidence of basin submergence in part of Sundarban mangrove delta, India Arabian Journal of Geosciences 11639

Tripathi S K, Resmi S, Baraik S, Sengupta D and Lahiri A(2018b) Channel Controlled Foraminiferal Distribution off Bakkhali, West Bengal, India Bulletin of the Marine Geology 33 82-93

Uddandam P R, Prasad V and Rai J (2017) Dinoflagellate cyst distribution in sediments of western Bay of Bengal: Role of sea surface conditions Palaeogeography Palaeoclimatology Palaeoecology 483 31-48

Uddandam P R, Prasad V, Thakur B and Manoj M C (2018) Cristadinium striaospinosa, a dinoflagellate cyst from the tropical region Journal of Paleontological Society of India 63 73-80

Verma K, Bharti S K and Singh AD (2018) Late Glacial-Holocene record of benthic foraminiferal morphogroups from the eastern Arabian Sea OMZ- Paleoenvironmental implications Journal of Earth System Sciences 127 1-15

Verma P and Singh A (2019) Early Oligocene (Rupelian) dinoflagellate cysts and calcareous nannofossils from Lumpy Clay Member of Maniyara Fort Formation, Kutch, Gujarat, India Current Science 116 1571-1580. 